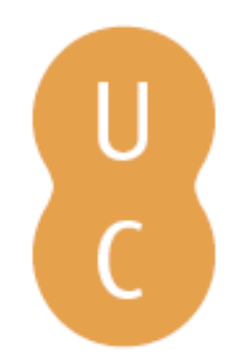

\title{
pombalina
}

\section{A tradição dos Sete Sábios: o Sapiens enquanto paradigma de uma identidade}

Autor(es): Leão, Delfim Ferreira

Publicado por: Centro de Estudos Clássicos e Humanísticos; Imprensa da Universidade

URL

persistente: URI:http://hdl.handle.net/10316.2/31542

DOI: $\quad$ DOI:http://dx.doi.org/10.14195/978-989-8281-23-4_2

Accessed : $\quad$ 26-Apr-2023 16:04:39

A navegação consulta e descarregamento dos títulos inseridos nas Bibliotecas Digitais UC Digitalis, UC Pombalina e UC Impactum, pressupõem a aceitação plena e sem reservas dos Termos e Condições de Uso destas Bibliotecas Digitais, disponíveis em https://digitalis.uc.pt/pt-pt/termos.

Conforme exposto nos referidos Termos e Condições de Uso, o descarregamento de títulos de acesso restrito requer uma licença válida de autorização devendo o utilizador aceder ao(s) documento(s) a partir de um endereço de IP da instituição detentora da supramencionada licença.

Ao utilizador é apenas permitido o descarregamento para uso pessoal, pelo que o emprego do(s) título(s) descarregado(s) para outro fim, designadamente comercial, carece de autorização do respetivo autor ou editor da obra.

Na medida em que todas as obras da UC Digitalis se encontram protegidas pelo Código do Direito de Autor e Direitos Conexos e demais legislação aplicável, toda a cópia, parcial ou total, deste documento, nos casos em que é legalmente admitida, deverá conter ou fazer-se acompanhar por este aviso.

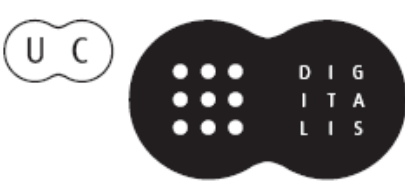


Colecção Autores Gregos e Latinos Série ENSAIOS

\section{Delfim Ferreira Leão José Ribeiro Ferreira Maria do Céu Fialho}

CIDADANIA E PAIDEIA

Na Grécia Antiga 


\title{
A tradiçấo dos Sete Sábios O SAPIENS ENQUANTO PARADIGMA DE UMA IDENTIDADE
}

\author{
Delfim Ferreira Leão
}




\section{MAGISTER DIXIT: O PAPEL FORMATIVO do SÁBIO ${ }^{\mathrm{I}}$}

A literatura gnómica ou de sentenças conheceu uma grande fortuna na antiguidade e a sua origem perde-se na própria raiz dos tempos. De facto, são inúmeros os exemplos de obras em que nos aparece determinada personalidade a aconselhar uma outra sobre a melhor forma de actuar. Este esquema de base conhece muitas formulaçóes e variantes; duas das mais frequentes consubstanciam-se na figura do sábio que orienta um soberano sobre o tipo de conduta a adoptar ou, na sua versão mais familiar, na imagem do pai que procura zelar pela formação do filho, dispensando-lhe os conselhos que a vida ensinou. O Oriente Próximo fornece-nos um amplo espectro de escritos com este cariz e vamos encontrá-los também em inúmeras outras literaturas, sem que isso implique necessariamente uma relação de dependência directa, já que ideias semelhantes podem ter sido desenvolvidas por povos distantes uns dos outros e de forma autónoma. ${ }^{2}$ De resto, que este

${ }^{1}$ Todas as traduçôes que figuram ao longo deste trabalho são da nossa autoria e feitas a partir do original grego ou latino. Salvo expressa indicação em contrário, as datas referidas remetem para um período anterior à nossa Era. Na elaboração deste estudo, recuperámos o essencial da argumentação que desenvolvemos em dois trabalhos anteriores: Leão (2000); (2003).

${ }^{2}$ Para um conspecto deste tipo de 'wisdom literature', vide West(1997). 
modelo simples continua activo e funcional, mostra-o uma infinidade de filmes produzidos pela indústria do cinema, onde a figura do mestre (com frequência industriado em 'artes orientais', assimiladas com um grau variável de eclectismo e rigor) prossegue a nobre missão de esclarecer e formar quem com ele se cruza.

No domínio da literatura grega, que agora nos ocupa mais em particular, o influxo deste tipo de material é detectável desde muito cedo também. Evocaremos apenas alguns exemplos, que ajudarão a atestar esta realidade bem conhecida dos estudiosos da antiguidade clássica. Em Homero, basta pensar na figura de Nestor, que se destaca pela ponderação das suas palavras, em particular na Ilíada. De resto, ele e outros seis guerreiros formavam uma espécie de conselho mais restrito de Agamémnon, o comandante-chefe da coligação grega que integrou a expedição a Tróia. ${ }^{3}$ Inesquecível é também o quadro dos anciáos que rodeavam Príamo e que, afastados embora dos combates devido ao peso da idade, mereciam, na qualidade de oradores, ser comparados ao inebriante canto das cigarras. ${ }^{4}$

No caso dos Trabalhos e Dias, o mesmo esquema conhece um aproveitamento ainda mais significativo. Sem querermos retomar agora a debatida questáo da eventual influência directa de textos sumérios, babilónios ou egípcios sobre esta obra, o certo é que a sua estrutura de base assenta no tema do conselheiro. Uma das notas de novidade de Hesíodo parece residir, precisamente, no

\footnotetext{
${ }^{3}$ Cf. Il. 2.400-9.

${ }^{4}$ Il. 3.146-52.
} 
facto de o destinatário das suas admoniçôes ser não um rei ou um filho, mas o próprio irmão (Perses), a quem procura reconduzir ao bom caminho, pese embora o facto de este haver tentado apoderar-se da parte que lhe cabia na herança paterna. ${ }^{5}$ Além dos inúmeros preceitos e sentenças, que têm presença obrigatória em textos de carácter gnómico, Hesíodo serve-se também de outras estratégias expositivas que conhecerão igualmente grande fortuna na literatura sapiencial: a fábula e o mito. ${ }^{6}$

O facto de, na Ilíada, Agamémnon aparecer rodeado de um grupo de sete homens da sua confiança está ainda longínquo da lenda que tenderá a fixar um colégio de Sete Sábios, a quem eram atribuídas sentenças memoráveis, proferidas no decurso de encontros com personalidades igualmente famosas. $\mathrm{O}$ contexto histórico que envolve algumas dessas figuras (como Tales, Sólon, Creso) sugere que a tradição terá começado a delinear-se durante a Época Arcaica, em particular entre os sécs. VII-VI. A este facto não será alheia a circunstância de, ao longo daquele período, a Grécia haver experimentado grandes tensôes políticas e sociais, que foram acompanhadas pelo surgimento da figura dos legisladores e de governos autocráticos, bem

${ }^{5}$ Ainda assim, em alguns momentos Hesíodo também se dirige aos reis, para exortá-los a respeitar a justiça de Zeus; e.g. Op. 24873.

${ }^{6}$ Referimo-nos à fábula do falcão e do rouxinol (Op. 202-12) e aos mitos de Pandora (42-105) e das Cinco Idades (106-201). Para uma sinopse do aproveitamento da tradição gnómica noutros autores gregos, desde a Época Arcaica até ao período romano, vide Wehrli(1973); Rodríguz Adrados (1994) 130-7. 
como por intensas relações com a Pérsia e a Ásia Menor, cuja opulência económica exercia sobre o imaginário grego tanto um sentimento de admiração como de censura, com frequência mesmo acintosa.

Não obstante a relativa antiguidade cronológica de certos aspectos ligados à vivência de figuras que viriam a ser contadas entre os sapientes, é em Heródoto que podemos surpreender os primeiros assomos literários desta lenda. De resto, a imagem do conselheiro acaba por ser um Leitmotiv na obra do historiador de Halicarnasso. É o que se verifica, por exemplo, em relação a personalidades como o ateniense Sólon e Âmasis, o último grande faraó da dinastia saíta, que partilham entre si o papel de conselheiro ponderado. ${ }^{7}$ Da mesma forma que Sólon avisa Creso, rei da Lídia, contra a imprudência de ignorar a constante mutabilidade das coisas humanas (1.32.1-9), o faraó aconselha o tirano de Samos, Polícrates, a interromper a sua perigosa carreira de sorte, desfazendo-se de algum pertence que considerasse precioso, pois estava consciente de como a divindade era invejosa da fortuna dos homens (3.40.2). Ao contrário de Creso, cuja incompreensão do profundo significado das palavras do hóspede ateniense o lança no caminho da desgraça, Polícrates acatou o conselho do monarca egípcio, atirando ao mar um anel com uma esmeralda, de que muito gostava. Mas essa mesma jóia acabaria por lhe voltar às máos no bucho de um grande peixe que

7 Lattimore (1939), 24, Lattimore coloca Âmasis na galeria dos conselheiros trágicos, que, além de Sólon, integra também Bias, Pítaco e até o próprio Creso (junto de Cambises), mas cujo representante mais acabado se encontra na pessoa de Artábano. 
um pescador lhe oferecera. Ao tomar conhecimento disto, o faraó compreendeu que não podia ter um fim feliz quem era táo aventurado a ponto de recuperar um objecto de que se havia desfeito e, assim, rompeu os vínculos de hospitalidade que o ligavam ao tirano, a fim de não ser afectado pela desgraça que certamente o atingiria. ${ }^{8}$ Embora Âmasis também vá ficar ligado ao ciclo dos Sete Sábios, ${ }^{9}$ a realidade é que, tanto em Heródoto como na tradição posterior, se destacam em particular as entrevistas patrocinadas por Creso e os conselhos que ele recebe de figuras como Tales (1.74.2; 75.3-4), Bias (ou Pítaco, 1.27.1-5) e Sólon (1.29-32). Os contornos que envolvem a relação com este último constituem o relato mais significativo de todos, a ponto de atingir o estatuto de modelo paradigmático da forma como o diálogo entre um sábio grego e um monarca oriental poderia ser abordado. ${ }^{10}$

A importância de Creso na génese da tradição dos Sete Sábios vai ao encontro da fama que o soberano gozava entre os Gregos e à qual não será alheia, pela certa, a influência délfica, facto que facilmente se compreende se aceitarmos a historicidade das oferendas magníficas

8 Pormenores em 3.39-43. Para outras informaçôes sobre Âmasis, vide $2.154 .3 ; 2.162$ e 2.169.

${ }^{9}$ Conforme se verá na análise ao Conuiuium de Plutarco (infra secção 2.1).

${ }^{10}$ Heródoto menciona também Quílon (1.59.2-3), Periandro $(1.20 ; 23)$ e o cita Anacársis (4.76-7). Este último virá a integrar o círculo dos sábios; a inclusão deste 'bárbaro' constitui não apenas uma nota de significativa imparcialidade, como permitirá ainda criticar certos aspectos da cultura grega, através dos olhos de um estrangeiro náo maculado ainda por certos vícios da civilização. Vide infra secção 2.1 . 
feitas ao oráculo pelo chefe lídio. ${ }^{11}$ Para mais, algumas das famosas máximas inscritas no átrio do templo de Apolo eram atribuídas aos sapientes que passaram pela sua corte, de modo que os conselhos de moderação que vemos, por exemplo, aplicados na conversa entre Sólon e Creso se confundem com a própria moralidade do oráculo. ${ }^{12}$ Por outro lado, embora a indicação do número sete ainda esteja ausente em Heródoto, será essa a fórmula adoptada para designar os sapientes no seu conjunto. ${ }^{13}$ Ora é bem conhecida a importância que este algarismo possui em muitos outros relatos e culturas, mas náo se afigura improvável que ele acuse, também por esta via, alguma relação com os interesses délficos. De facto, este era, precisamente, o dia do aniversário de Apolo (sete do mês de Byzios, em Fevereiro-Março), razão pela qual, de início, as consultas seriam ministradas exclusivamente nessa data e só depois, para atender à grande afluência, se estenderiam a outras alturas. ${ }^{14}$

${ }^{11}$ Cf. Heródoto, 1.50-51. Em reconhecimento, os Délfios outorgaram a Creso e aos Lídios privilégios especiais (1.54.2): a promanteia (prioridade na consulta do oráculo entre elementos do mesmo grupo, neste caso entre os Bárbaros); a ateleia (isenção de pagamento do imposto preliminar para a consulta do oráculo); proedria (lugar reservado nos espectáculos, geralmente nas primeiras filas) e ainda o direito de se tornarem cidadãos de Delfos.

${ }^{12}$ E.g. Platão, Chrm. 164d-165a; Pausânias, 10.24.1; Diógenes Laércio, 1.63.

13 Heródoto refere-os apenas de maneira indeterminada (1.29.1): «passam por Sardes, então no cume da sua riqueza, todos os demais sábios da Hélade que nessa altura viviam, levados cada um por seu motivo".

${ }^{14}$ É tentadora, igualmente, a hipótese de influência oriental, pois no poema de Gilgamesh da antiga Babilónia alude-se a um grupo de sete homens sábios que vieram ajudar na construçáo das 
Em suma: desta breve resenha, afigura-se legítimo reter, antes de mais, que a imagem do sapiens constitui um dos grandes temas da própria tradição popular, tendo conhecido uma ampla difusão na antiguidade mais remota. Na literatura grega, a sua presença surpreende-se desde Homero, mas os indícios da fixação de um grupo de figuras de contornos histórico-lendários, que marcaram o imaginário grego entre os sécs. VII-VI, notam-se, pela primeira vez, em Heródoto. Embora a lenda não tenha ainda o perfil bem definido, na obra do historiador, detectam-se já alguns aspectos que lhe são característicos: a marca de certas zonas de influência, como a Iónia (Pítaco, Bias e Tales), Atenas (Sólon) e o Peloponeso (Quílon, Periandro); o papel de Delfos, enquanto elo de ligação entre estas figuras. ${ }^{1} \mathrm{~A}$ partir daqui, o cânone tenderá a estabelecer-se, não deixando, porém, de ser enriquecido com novos contributos e desenvolvimentos. É esse caminho que nos propomos evocar rapidamente na próxima secção, para nos determos, com mais pormenor, no contributo de Plutarco.

\section{A literatura De BanQuete}

Embora Heródoto constitua o primeiro testemunho literário a acusar a génese de um grupo estável de sapientes e a estabelecer até o modelo para alguns dos encontros mais famosos, é no Protágoras

muralhas da cidade. Em todo o caso, já no início desta análise chamávamos a atenção para a necessidade de ter em conta que ideias semelhantes podem ocorrer em lugares diferentes, sem que isso implique uma relação de dependência directa entre si.

${ }^{1}$ Oportunas as observaçóes de Busine (2002) 17-27, esp. 27. 
(343a) de Platão que se encontra a primeira relação completa dos Sete Sábios. As figuras escolhidas são Tales, Pítaco, Bias, Sólon, Cleobulo, Míson e Quílon. Segundo o filósofo, o motivo que justificara a sua reunião teria sido a vontade de consagrar a Apolo certas máximas, como primícias da sua sabedoria. A referência directa ao templo oracular ajuda a sustentar a hipótese de que o encontro terá acontecido em Delfos, se bem que o passo seja um tanto ambíguo, já que se afirma que esse era o destino das sentenças e não propriamente o ponto de reuniáo. Por isso, a hipótese de Sardes também seria oportuna, dada a estreita ligação entre Creso, a figura dos sábios e a ética apolínea. Em todo o caso, a tradição posterior acabou por conceber estas e outras variantes, conforme demonstra um esclarecedor passo de Diógenes Laércio, que valerá a pena evocar (1.40):

Ora Arquetimo de Siracusa descreven a sua [dos Sete Sábios] reunião na corte de Cípselo, na qual afirma ele próprio ter participado; já Éforo colocou-a na de Creso, sem a presença de Tales. Alguns afirmam que eles se juntaram no Paniónio, em Corinto e em Delfos.

Não obstante a informação de Diógenes, desconhece-se hoje a natureza dos trabalhos mencionados e o próprio Plutarco, na lista que fornece da literatura ligada ao tema do banquete, ${ }^{2}$ não refere nenhum deles, se bem que essa enumeração se prenda com obras de carácter filosófico, facto que talvez explique a omissão. Em todo o

${ }^{2}$ Mor. 612d. 
caso, o testemunho do doxógrafo agora evocado mostra a atençáo que o tema despertou na literatura produzida entre a Época Clássica e a altura em que esteve activo, na viragem do séc. II para o séc. III da nossa Era. Na verdade, Diógenes representa um momento da tradição em que as diferentes abordagens da questão se encontravam já cristalizadas e disso fornece abundantes exemplos na sua obra. No Livro I, depois do proémio e antes da consideração dos filósofos propriamente ditos, o biógrafo recorda, ao longo de uma centena de capítulos, inúmeros aspectos ligados à existência daqueles homens que, desde os tempos de antanho, haviam sido considerados sophoi. ${ }^{3}$ Destes, é a Tales e a Sólon que analisa com maior cuidado, facto que espelha o peso que estas figuras detinham já na lenda. ${ }^{4}$ Ao tecer a biografia destas personalidades, Diógenes está, naturalmente, a par das variantes da tradição, que opta, de resto, por explorar, fornecendo, assim, um elucidativo conspecto dos diferentes estádios da sua evolução, que será pertinente recordar (1.41-42):

Discute-se também qual o seu número. Leândrio, de facto, em vez de Cleobulo e de Mison, optou por Leofanto, filho de Górsias, de Lébedos ou de Éfeso, e pelo

3 Conforme ele mesmo esclarece (1.122), antes de fazer a transição para a filosofia iónica, de que Tales, uma das figuras evocadas também como sábio, fora o iniciador.

${ }^{4}$ Os capítulos encontram-se distribuídos na seguinte proporção: Tales (22-44); Sólon (45-67); Quílon (68-73); Pítaco (74-81); Bias (82-88); Cleobulo (89-93); Periandro (94-100); Anacársis (101105); Míson (106-108); Epiménides (109-115); Ferecides (116122). 
cretense Epiménides; já Platão, no Protágoras, faz entrar Mison para o lugar de Periandro; Éforo substitui Mison por Anacársis; outros ajuntam ainda Pitágoras. Dicearco regista quatro nomes que também reconhecemos - Tales, Bias, Pitaco, Sólon - e refere outros seis (de entre os quais selecciona três): Aristodemo, Pânfilo, o lacedemónio Quílon, Cleobulo, Anacársis e Periandro. Alguns acrescentam Acusilau, filho de Cabas ou de Escabras, natural de Argos. Mas Hermipo, no Sobre os Sábios, alinha dezassete, a partir dos quais diferentes pessoas formam grupos diferentes de sete. São eles Sólon, Tales, Pitaco, Bias, Quilon, Mison, Cleobulo, Periandro, Anacársis, Acusilau, Epiménides, Leofanto, Ferecides, Aristodemo, Pitágoras, Laso, filho de Carmântides ou de Sisimbrino ou, de acordo com Aristóxeno, de Cábrino, natural de Hermione, e Anaxágoras. Hipóboto, na Lista dos Filósofos, alinha Orfeu, Lino, Sólon, Periandro, Anacársis, Cleobulo, Mison, Tales, Bias, Pitaco, Epicarmo e Pitágoras.

O texto quase dispensa comentário, pois é, por si mesmo, bem ilustrativo da riqueza da tradição ligada aos Sete Sábios, bem como das possibilidades de escolha e combinação dessas figuras. Aogrupo pertenciam inclusive tiranos como Periandro, que, mesmo quando náo ocupavam o posto de sapiente, poderiam desempenhar um papel igualmente importante ao patrocinarem encontros de sophoi. ${ }^{5}$ Diógenes, que náo pretende

${ }^{5}$ No passo em análise, Diógenes não refere Pisístrato, embora reconheça, ao encerrar a biografia das figuras que escolhera, que alguns autores o catalogam também entre esses homens ilustres (1.122). 
descrever um encontro com estas personalidades, evita a obrigação de eleger o tradicional número de sete, pelo que opta por traçar a biografia das onze figuras que lhe despertavam maior interesse ou sobre as quais circularia maior abundância de informação. $\mathrm{O}$ delineamento da sua existência segue um esquema relativamente estável. Os elementos constantes prendem-se com os três pontos fundamentais na vida: nascimento, maturidade (akme) e morte. Os traços sujeitos a maior variação ligam-se às sentenças e opinióes conotadas com a personagem retratada. ${ }^{6}$

Antes de passarmos ao caso de Plutarco, que nos motivará uma reflexão maior, importa retomar um factor ligado ao contributo de Platão. Ainda mais significativo do que o aspecto episódico de ter sido ele o primeiro a apresentar uma lista de Sete Sábios, que se haviam reunido com um objectivo específico, é o facto de o filósofo ter criado um modelo de exposição que conhecerá, igualmente, inúmeras imitaçóes e aproveitamentos. Referimo-nos ao diálogo filosófico e, em particular, à forma adoptada no Banquete. Para melhor ponderarmos a importância dessa criação literária, importa reflectir um pouco sobre o lugar que o próprio symposion ocupava na cultura grega. ${ }^{7}$

${ }^{6}$ Estes exemplos de sabedoria popular designam-se geralmente por termos como gnome, apophthegma, apomnemoneuma, chreia. Sobre as características, origem e tradição deste tipo de literatura e sua utilização na obra de Diógenes, vide Kindstrand (1986) 217 243; Gigante (1986) 16-18.

7 Nesta breve sistematização, iremos aproveitar algumas das ideias expressas em Murray (1994). 
$\mathrm{O}$ acto ritualizado de partilhar a comida e a bebida pode revelar-se muito importante, na medida em que constitui uma excelente oportunidade para vencer barreiras e firmar laços de natureza social, antes de mais, mas também de cariz político e religioso. De resto, as ocasióes em que a refeição comum era praticada, em termos gerais, na Grécia da Época Arcaica e Clássica, ajudam a tornar mais clara esta realidade. Salvo algumas notáveis excepções (como o oráculo de Apolo em Delfos e o culto a Perséfone e Deméter em Elêusis), a religião grega caracterizava-se por não ter uma casta sacerdotal fixa, pelo que as obrigaçóes religiosas acabavam por recair na esfera de competência de certos magistrados públicos. Desta forma, os festivais religiosos assumiam um carácter de 'Estado', enquanto elucidativo sinal de civismo, onde a refeição em conjunto poderia ocupar um posto importante. Aliás, em Atenas, uma das formas de reconhecimento público consistia em garantir a determinada pessoa a refeição a expensas da cidade no Pritaneu, na companhia de outros membros ilustres da pólis. Na sociedade estratificada e estanque de Esparta, o acto de comer em conjunto (syssitia) constituía uma forma institucionalizada de fortalecer os laços entre os cidadáos, cuja influência se sobrepunha ao domínio privado da célula familiar. A vertente de lazer, que acompanhava também grande parte desses momentos, acabaria por se traduzir em criaçóes culturais, que encontravam nesse espaço um enquadramento de eleição. Se não quisermos entrar no domínio das provas desportivas, basta pensar em manifestaçóes artísticas como a música, a poesia, a retórica 
e a discussão político-filosófica, para vermos plenamente justificadas as implicaçôes culturais destes eventos. ${ }^{8}$

Deixámos para o fim aquele tipo de refeição que interessa mais aos nossos objectivos: o symposion privado. Em teoria, qualquer pessoa com alguns recursos poderia promover uma reuniáo informal com os amigos; no entanto, os gastos ligados a esta forma de diversão, bem como o tempo que obrigava a despender, fazem com que o banquete seja uma realidade conotada, preferencialmente, com o estilo de vida aristocrática, realidade que acarreta algumas consequências dignas de nota. Antes de mais, saliente-se o facto de constituir uma comensalidade inter pares e de, portanto, ser mais fácil promover a igualdade de expressão; depois, a contingência de ocorrer num 'espaço masculino' (andron), aspecto que poderia causar alguma estranheza noutras culturas. ${ }^{9}$ Isto não implica que as mulheres estivessem ausentes, se bem que a sua assistência náo abonasse muito em favor da respectiva reputação. Na realidade, o symposion podia cumprir também a funçáo de iniciar um jovem a vários níveis, entre eles a actividade sexual. Daí que a relação de pederastia fosse uma presença assídua nestes

8 Não é por acaso que, ao longo dos últimos anos, se intensificaram os estudos relativos ao contexto de apresentação da poesia grega, bem como às características da audiência que acompanhava a execução da lírica coral, monódica e elegíaca.

${ }^{9}$ Conforme nos dá conta Cícero (Verr. 2.1.26.66), ao apresentar as desculpas que um grego do séc. I dava a um oficial romano, interessado em seduzir a filha do anfitriáo: «não é costume dos Gregos permitir que as suas mulheres se reclinem num conuinium de homens». 
espaços; ${ }^{10} \mathrm{o}$ mesmo se diga em relação à prática do amor livre, patrocinado por mulheres de moral duvidosa (hetairai), contratadas especificamente para a animação do banquete, juntamente com as flautistas e bailarinas.

Todos estes factores contribuíam para que o symposion constituísse um meio privilegiado para reforçar laços de amizade pessoal e ideológica, traduzidos em lealdade entre os elementos de determinado grupo (hetaireia), que poderiam revelar-se determinantes na altura de solucionar problemas pessoais ou de prosseguir uma carreira política. Aliás, estes propósitos viam-se facilitados pelo papel que o vinho detinha no banquete e que acabava por ser até mais importante do que a refeição propriamente dita, conforme se deduz do sentido primitivo do próprio termo symposion ('beber em conjunto'). ${ }^{11}$ A bebida aproximava os convivas, da mesma forma que o espaço relativamente limitado da sala de jantar e o facto de se encontrarem reclinados ajudavam a concentrar as atençôes dos comensais. Por isso, era fundamental que o vinho fosse misturado com água, a fim de permitir o prolongamento da conversa e da diversão, sem que o convívio descambasse em

${ }^{10} \mathrm{Tal}$ como acontecia nos ginásios, igualmente assimilados a ocupaçóes de natureza aristocrática.

${ }^{11}$ Já o latim conuiuium coloca a tónica na partilha do espaço ('viver em conjunto') e, em consequência, na ideia de 'compartir a refeição'. Ao comentar a etimologia do termo, Cícero (Cat. M. 13.45) acentua bem essa diferença relativamente aos Gregos. Em Tusc. 5.41.118, é ainda mais expressivo, ao referir «aquela norma que se observa nos conuiuia gregos: 'ou se póe a beber ou se póe a andar' (aut bibat aut abeat)». 
excessos, colocando em risco a harmonia do encontro. ${ }^{12}$ Mesmo com estes cuidados, o banquete comportava, por vezes, uma dimensão mais violenta, em particular no seu termo, sobretudo quando resultava do convívio a necessidade de cometer alguma prova que ajudasse a cimentar os laços de lealdade (pistis) entre os companheiros de mesa. Nas vésperas da partida da armada para a Sicília (em 415), Atenas viveria momentos de escândalo e de pavor, com dois sacrilégios que teriam sido perpetrados no contexto do symposion: a mutilaçáo das estátuas de Hermes e a paródia aos Mistérios de Elêusis. Embora o excêntrico aristocrata Alcibíades só pareça ter estado envolvido na questão dos Mistérios, as fontes espelham alguma ambiguidade favorável à confusão entre os dois sacrilégios, que poderia ter sido aproveitada pelos inimigos do estadista. ${ }^{13}$ Já os antigos sentiram dificuldades em esclarecer os reais contornos do escândalo, que ficou para a posteridade como exemplo dos perigos do exibicionismo destrutivo, fosse ou não motivado por objectivos políticos de maior alcance.

12 Beber vinho puro era, aliás, uma característica distintiva dos bárbaros; por outro lado, a partir da Época Helenística, a intensificação dos contactos com a Macedónia e Roma levou a que a discussáo ligada ao ritual da refeição propriamente dita (deipnon) viesse a ser encarada também com importância crescente. Vide Murray (1994) 5-6; STADTER (1999).

${ }^{13}$ Em fontes mais tardias, como Diodoro (13.2.3-4; 5.1), a ligação aos dois sacrilégios encontra-se já bem patente. No entanto, Tucídides (6.27-28.2) distingue os dois crimes, mas deixa entrever (6.28.2) que, aos olhos dos inimigos, Alcibíades seria suspeito de estar por detrás também da mutilação dos Hermes ou pelo menos de lhe dispensar simpatias. Sobre estes crimes relacionados com práticas de 'impiedade’ religiosa (asebeia), vide LeÁo (2004). 
Depois destas breves notas relativas ao posto que o banquete ocupava na cultura grega, chegou a altura de regressar a Platáo e de procurar entender os motivos que justificaram este pequeno excurso num trabalho em que se pretende reflectir sobre a tradição dos Sete Sábios. Os inícios da literatura de banquete podem encontrarse já na descrição de convívios divinos e humanos, que ocorrem com alguma frequência em Homero. ${ }^{14}$ Contudo, ao imaginar o Banquete em casa do jovem poeta trágico Ágaton, onde várias personalidades se tinham reunido para discutir os poderes de Eros (destacando-se entre elas a figura de Sócrates), Platão havia de tornar-se no primeiro autor a verter o ambiente ritualizado do symposion numa obra literária. Com este passo, fixou o modelo para uma forma de utilização do diálogo filosófico em contexto de banquete que será depois retomada por inúmeros autores. ${ }^{15}$

Ora é precisamente neste ponto que a questão volta a encontrar-se com o tema dos sapientes. De facto, entre os textos relativos a esta tradição, aquele que será porventura mais significativo é o Conuiuium Septem Sapientium de Plutarco. ${ }^{16}$ Que a matriz platónica está na génese deste opúsculo do biógrafo de Queroneia é um facto mais do

${ }^{14}$ E.g. Il. 1.595-611; Od. 4.15-19.

${ }^{15}$ Para os nossos objectivos, não se afigura pertinente discutir se o Banquete de Xenofonte é ou não anterior ao de Platáo, já que, dos dois autores, foi claramente este último que exerceu a influência mais determinante.

16 Para uma versão portuguesa, com notas, desta obra de Plutarco, vide LEÃo (2008a). As reflexôes agora feitas sobre os antecedentes da tradição do banquete e sobre as características que o marcam são, em boa parte, comuns à introduçáo feita à tradução daquele opúsculo. 
que conhecido dos estudiosos, pelo que nos dispensamos de retomar esse problema. Menos evidente se afigura, no entanto, a hipótese de existir uma ou várias obras de permeio, que tivessem explorado já a conjugação do encontro dos Sete Sábios com a realização de um banquete e servissem, portanto, de modelo a Plutarco. Em si, a ideia revela-se bastante plausível, mas falta, no entanto, um aspecto fundamental: um exemplo claro e inequívoco de que as coisas se passaram desse modo. ${ }^{17}$ É certo que o texto de Diógenes anteriormente comentado (1.40) aponta nessa direcção, mas isso não impede liminarmente que o Symposion de Plutarco tenha sido a fórmula encontrada pelo autor a fim de conseguir margem de relativa inovaçáo, dentro de uma tradição já muito saturada por tratamentos análogos. ${ }^{18}$

\subsection{O Banquete dos Sete Sábios de Plutarco}

Um dos primeiros anacronismos que se pode apontar ao Banquete dos Sete Sábios reside no facto de

${ }^{17}$ Rodríguez Adrados (1994), 139-40, sustenta que o tema original da relação rei/sábio, combinado com o esquema do banquete platónico, foi modificado em ambiente cínico (possivelmente logo a partir do séc. IV) e expandido através do contributo de material antiquário e dos géneros antológicos helenísticos. Seria esta amálgama de contributos que teria influenciado Plutarco; o estudioso vai ainda mais longe e sugere como provável precedente a modificação do diálogo socrático por Menipo.

18 Ainda assim, no prólogo do Conuiuium (146b), Díocles, o narrador, propóe-se apresentar a versão correcta do symposion, já que circulavam outros relatos sem fundamento. Embora esta afirmação possa constituir um mero expediente narrativo, não é improvável que seja uma alusão a tratamentos anteriores e, de certa maneira, semelhantes ao que Plutarco agora adoptava. 
Plutarco pressupor a contemporaneidade dos vários sapientes envolvidos. Pensar que o autor não tinha consciência do erro está fora de questão, conforme se pode constatar na biografia que fez de Sólon, um dos participantes no banquete. ${ }^{19} \mathrm{Se}$, nesse ponto, o polígrafo defendia o relato do encontro com o soberano lídio em nome do seu peso ético, mais pertinente essa explicação se torna neste caso, já que o encontro dos Sete Sábios representa, em si mesmo, uma irrealidade histórica. Por outro lado, Plutarco está, naturalmente, a seguir uma tradição enraizada havia muito tempo no pensar comum, que o obriga a colocar o diálogo num passado distante. $^{20}$

O convite para o encontro foi endereçado pelo tirano Periandro, tendo como destinatários os seguintes sábios: Sólon, Tales, Anacársis, Bias, Cleobulo, Pítaco e Quílon. No entanto, aparecem muitas outras figuras no symposion, inclusive femininas, ajudando a construir a originalidade do opúsculo, conforme veremos mais adiante. As outras personagens não gozam todas, porém, do mesmo nível de intervenção de que dispóem os sapientes. ${ }^{21}$ Contudo, no queà identidade dos Sete Sábios

${ }^{19}$ Cf. Sol. 27.1. Na secçáo 3, iremos ponderar com mais cuidado a questáo cronológica, que se colocava, de resto, já para Heródoto, em moldes semelhantes.

${ }^{20}$ Facto que constitui, de resto, uma nota de excepçáo dentro dos seus escritos; o único outro caso é o De genio Socratis. Cf. Aalders (1977) 28-29 e n. 7.

${ }^{21}$ De facto, são dezassete as personagens, sem contar com Gorgos, irmão de Periandro, que entra na parte final do symposion (160d). Contudo, o facto de algumas das figuras tomarem a palavra de forma tradicional e segundo uma ordem fixa, na primeira parte do diálogo (151e, 154d, 155c), permite identificar quais eram, 
diz respeito, Plutarco mostra-se bastante próximo do colégio definido por Platão: exclui, como ele, Periandro, mas coloca Anacársis no lugar de Míson. ${ }^{22} \mathrm{~A}$ eliminação de Periandro do núcleo dos sábios justifica-se, pela certa, devido ao facto de ele ser tirano e de o opúsculo revelar uma animosidade de fundo em relação a esta forma de governo. Ainda assim, Cleobulo, autocrata de Lindos, continua a figurar entre os sapientes, embora detenha um papel bastante secundário e a sua presença deva explicar-se, também, pela intenção de colocá-lo junto da filha, Cleobulina. Em termos comparativos, Periandro acaba por desempenhar uma função mais importante, na qualidade de anfitriáo, ainda que a sua presença se vá desvanecendo, sobretudo a partir do momento em que se começa a fazer o elogio do regime democrático, a ponto de caber a Sólon a honra de fechar o banquete (164c-d). Nesta galeria, o caso de Pítaco é igualmente digno de nota, dado que, durante algum tempo, esteve à frente dos destinos de Mitilene com plenos poderes. Fê-lo, porém, na qualidade de soberano eleito pelo povo (aisymnetes) e, depois de ter acalmado o clima de dissensão civil, mostrou, como Sólon em Atenas, a prudência de abandonar o poder, com ele partilhando a fama de legislador. ${ }^{23}$

efectivamente, os Sábios. Vide Defradas, Hani \& Klaerr (1985) I79-8 I.

${ }^{22}$ Possivelmente na esteira de Éforo, já que a lista de Demétrio de Fáleron admitia a presença de Periandro; cf. supra Diógenes Laércio, 1.41. Noutro ponto (Mor. 385d), Plutarco refere a tradição, relativa às máximas de Delfos, que excluía tanto Periandro como Cleobulo, reduzindo o número de sábios a cinco.

${ }^{23}$ De resto, já Heródoto (1.27) e Platão (Prt. 338e-347a; $H p$. 
Em todo o caso, a presença de vários sábios conotados com regimes autocráticos deve constituir um sinal da antiguidade da tradiçáo que os contava nesse círculo. ${ }^{24}$ De facto, se é certo que, na viragem do séc. VII para o VI, a tirania era um regime existente e até característico da época, o mesmo não se poderá afirmar a respeito da democracia, que só mais tarde daria os primeiros passos. Há portanto um anacronismo no debate quando os sábios defendem o governo popular, do tipo daquele que envolveu os nobres persas em consideraçôes acerca da melhor forma de constituição. ${ }^{25}$ Desta maneira, a animosidade contra a tirania não deve fazer parte das fases iniciais da lenda. ${ }^{26} \mathrm{O}$ carácter odioso do termo é, sobretudo, uma consequência da acção dos Trinta Tiranos, que governaram Atenas em 404 e cuja actuação ficou marcada por uma violência extrema. Daí que em Platão já se note esse sentimento de crítica, que passaria à tradição posterior e conhece uma expressão clara no Conuiuium de Plutarco.

Sólon, Tales, Bias e Quílon pertenciam já ao núcleo estável dos Sete Sábios, além de terem a vantagem de não levantar os problemas que acabámos de analisar,

Ma. 281c; R. 335e) lhe atribuíam um lugar de eleição entre os sapientes; sobre as leis que o celebrizaram em Mitilene e as máximas que terá proferido, vide Diógenes Laércio, 1.75.

${ }^{24}$ Sobre a figura do tyrannos como sophos no Banquete dos Sete Sábios, vide em particular LEÃo (2009).

${ }^{25}$ Relatado por Heródoto (3.80-82).

${ }^{26} \mathrm{Na}$ primeira ocorrência do termo (frg. 19 WesT de Arquíloco), a tirania é classificada de 'poderosa' e, mesmo na segunda metade do séc. V, as palavras tyrannos e tyrannis aparecem usadas, ainda, com o sentido de 'rei, soberano', 'riqueza, poder', se bem que a cor semântica negativa também possa ocorrer. 
pelo que evitaremos deter-nos sobre eles. Todavia, no que a Anacársis diz respeito, interessa reflectir com mais pormenor. Heródoto refere-se a ele na altura em que descreve os costumes dos Citas e a aversão que estes nutrem por costumes estranhos, em particular se tiverem origem grega. Na versão do historiador (4.76), Anacársis é já apresentado com traços de sapiente, dado que, nas muitas terras por onde tinha viajado, deixara provas de elevada ponderação. De regresso a casa, Anacársis ficara impressionado com a festividade em honra da Magna Mater, que havia observado em Cízico, e comprometeu-se a instaurar o culto no seu país de origem, se conseguisse regressar a salvo. Já na Cítia, foi surpreendido a realizar esse ritual e viria a morrer às mãos do próprio irmão, o rei Sáulio. Desta forma, Anacársis tornava-se numa espécie de mártir da civilização grega. Heródoto (4.77) apresenta ainda uma outra versão dos eventos, embora a considere uma invenção. De acordo com este segundo relato, Anacársis teria frequentado uma escola na Hélade a mando do próprio rei; ao regressar, informou-o de que os Gregos eram dados a todo o tipo de saber, com excepção dos Lacedemónios. Apesar disso, estes últimos eram os únicos que revelavam capacidade para falar e ouvir com acerto. Esta variante retira a Anacársis a fama de ser um entusiasta da cultura grega. No entanto, a preferência pela discrição e laconismo dos Espartanos criou nele uma aura de 'bom selvagem', habilitado para criticar a opulência da civilização. A imagem de sábio austero será aproveitada, em particular, pela escola cínica, que 
fará dele um símbolo do despojamento e um paladino das suas ideias filosóficas. ${ }^{27}$ Ao colocá-lo no symposion promovido por Periandro, Plutarco encontrava-se na linha do influxo tradicional; no entanto, a figura deste sábio 'bárbaro' ia também ao encontro do objectivo de tornar o Banquete num espaço aberto à alteridade. Como tal, além da aristocracia grega maioritária, estava igualmente representada a sofisticação egípcia (através de Nilóxeno, enviado de Âmasis) e o nomadismo dos bárbaros do norte (Anacársis). ${ }^{28} \mathrm{~A}$ esta diversidade, vinham juntar-se ainda as marcas da sensibilidade feminina (Cleobulina) e de uma sabedoria mais popular (Esopo), sobre as quais falaremos de seguida.

Ao reflectirmos sobre o papel do symposion na literatura grega, chamávamos a atenção para o facto de o banquete ser, essencialmente, uma actividade conotada com o mundo masculino. Contudo, no Conuiuium imaginado por Plutarco estão presentes duas figuras femininas: Cleobulina e Melissa, esposa de Periandro. São ambas personagens mudas e ausentam-se antes do final do banquete, permitindo assim que a conversa evolua para outros temas (155d-e). Contudo, se a mulher

${ }^{27} \mathrm{O}$ seu aspecto descuidado faria lembrar o do cínico Diógenes, pelo que os partidários desta escola chegaram mesmo a atribuir-lhe a autoria de uma série de cartas onde sustentaria os preceitos cínicos; Cícero (Tusc. 5.32.90) cita um fragmento dessa pretensa actividade epistolar, comum, de resto, a boa parte das figuras ligadas ao círculo dos Sete Sábios.

${ }^{28}$ Plutarco serve-se também do cita para expor algumas das suas convicçóes éticas e filosóficas, nomeadamente em relação à melhor forma de organização política e doméstica (152a, 155a-c) e ao facto de ver na alma um instrumento de Deus (163d-f). Vide SchmidT (1999) 260-1. 
do tirano acaba por ser apenas um adorno, a pessoa de Cleobulina/Eumétis obriga a maior ponderação e tem, por isso, dividido os estudiosos. Em primeiro lugar, a presença de mulheres poderia ser vista apenas como um sinal da época de Plutarco, onde a influência de outras culturas faria com que a inclusão de mulheres 'sérias' no symposion fosse considerada uma escolha normal. Esta explicação simples revela-se oportuna, se bem que enfrente o óbice de, nas Quaestiones conuiuales, não se registarem participantes femininos. ${ }^{29}$ Por outro lado, nas Leis (780e), Platão regista que as mulheres podem juntar-se em refeiçóes públicas, mas não está a referir-se a banquetes mistos, o que invalida, naturalmente, a sua participação nos symposia usuais. Verificados estes condicionalismos, a opçáo de Plutarco de fazer entrar a figura de Cleobulina, ainda muito jovem, deve explicar-se talvez por outra via. Antes de mais, como novidade relativa e como forma de acrescentar ao ambiente algumas cenas quase domésticas, como é o facto de, logo à chegada a casa de Periandro, nos apresentar Cleobulina a tratar dos cabelos desgrenhados de Anacársis (148c-e). De alguma forma, parece dizer que o aspecto agreste do bárbaro cita estaria a ser modelado pela delicadeza de mãos gregas. De resto, as palavras de Tales, que cumprimenta a jovem com familiaridade, acentuam precisamente essa impressão, se bem que com a ideia de que eram mútuas as vantagens daquela relação próxima

${ }^{29}$ De facto, no passo (712e-f) que poderia ser apresentado para sustentar a posiçáo contrária, o que está em questão é mais o carácter vulgar do mimo do que a inclusáo de mulheres e crianças no banquete. Vide Mossman (1997) 124-5; Pordomingo Pardo (1999) 389-91. 
com o bárbaro. A influência benéfica de Cleobulina projecta-se, ainda, sobre o pai, ajudando a dulcificar-lhe o carácter e a tornar o seu governo 'mais próximo do povo' (demotikoteros). Desta forma, atenua-lhe igualmente o traço negativo de ser tirano de Lindos. ${ }^{30}$ Por último, Cleobulina contribui, também, para transformar o espaço do banquete numa cosmópolis dos vários tipos de sapiência: a jovem representaria, assim, uma sabedoria mais simples, permeada de intuição política e de humanidade, conforme se depreende das palavras que Tales profere a respeito dela. ${ }^{31}$

Para este mundo de sabedoria alternativa contribui ainda, grandemente, a figura de Esopo. Tal como Cleobulina, vários aspectos da sua vida têm como pano de fundo a lenda dos Sete Sábios, sem que nunca tenha sido considerado um deles. A sua presença no symposion deve-se, do ponto de vista da narrativa, ao facto de estar ao serviço de Creso, que o enviou quer à corte de Periandro quer ao oráculo de Delfos (150a). Este pormenor lança, de certa forma, alguma sombra sobre o mérito da sua participação, já que, segundo os dados da lenda, Esopo encontraria a morte em Delfos, por haver desrespeitado os sacerdotes do oráculo e os habitantes da região, acusando-os de simples parasitismo. Com esta nota discreta, Plutarco parece acenar à polémica latente com o círculo dos sapientes, dada a estreita ligação destes últimos com a moralidade

${ }^{30} \mathrm{E}$ justifica o nome alternativo por que é conhecida: Eumétis ('avisada, prudente').

${ }^{31}$ Vide Mossman (1997), 124-6, cujos argumentos seguimos, em parte, neste ponto da exposição. 
délfica. ${ }^{32}$ De resto, o facto de ser emissário de Creso serve de contraponto ao relativo desprezo que Sólon manifestara em relação ao monarca lídio (155b) e que encontra eco também na biografia do estadista (Sol. 28.1). No Conuiuium, Esopo encontra-se sentado num escabelo, junto do poeta ateniense, que está reclinado e num plano superior (150a). Cruzam-se, assim, as identidades do aristocrata e do antigo escravo, num mesmo espaço, mas separados por uma sensibilidade e estatuto diferentes: a integração de Esopo dentro do grupo não chega, portanto, a ser total, se bem que não redunde nunca em tensão. O fabulista fala diversas vezes ao longo do symposion e, em duas delas, toma o partido quer de Cleobulina quer de Periandro. No primeiro caso (154a-c), defende a jovem quando ela se abstivera de responder, por timidez, às palavras do médico Cleodoro, que lhe criticava a futilidade dos enigmas. A intervenção de Esopo é significativa, na medida em que, ao colocar-se ao lado de Cleobulina, está também a defender a mesma sabedoria popular que ele próprio representa. No segundo caso (152b-d), sai em auxílio de Periandro, que as tiradas anteriores dos sábios haviam, de alguma forma, isolado, já que exprimiam ideias contrárias à tirania. $\mathrm{Na}$ sua argumentação, Esopo entra novamente em discussão com Sólon, que se diverte com as palavras do antigo escravo, não o levando muito a sério. Contudo, esta intervençáo ajuda a reforçar o carácter de Esopo

${ }^{32}$ Cf. Heródoto, 2.134; Aristófanes, V. 1446-8. Vide ainda Defradas, Hani \& Klaerr (i985) i 84-6; Garcia Gual (i994); VAN DijK (I999) 
enquanto representante das massas populares, que tiveram, de resto, um papel importante na instalação de tiranias, cujo governo assumia, geralmente, um cariz anti-aristocrático, protegendo, em consequência, as classes inferiores que constituíam a sua base de apoio.

\section{Sólon e CReso: FASES NA EVOLUÇÃo de UM PARAdIGMA}

O encontro entre Sólon e Creso constitui um dos episódios mais famosos e mais discutidos da história da cultura clássica, em particular no contexto da tradição dos Sete Sábios. Embora estas duas personalidades tivessem captado a atençáo dos antigos de forma independente, o certo é que, depois de Heródoto haver narrado a conversa entre os dois homens, eles ficariam ligados de forma indelével. O estado actual das fontes leva a sustentar, com bastante segurança, que terá sido o historiador o primeiro a imaginar a entrevista entre Sólon e Creso, facultando assim quer o relato mais completo quer o modelo para os tratamentos subsequentes. ${ }^{33}$ A consciência desta realidade não obriga, naturalmente, a que os restantes testemunhos descrevam o encontro de forma exactamente igual. De resto, se as pequenas variantes na exposição reforçam a influência do padrão estabelecido por Heródoto, talvez ajudem, por outro lado, a esclarecer melhor o objectivo que terá levado cada autor a retratar o famoso episódio. $\mathrm{Na}$ verdade, acaba por ser esta, afinal, a razão que nos leva a analisar novamente um tópico que tem colhido, com frequência, a atenção dos estudiosos do mundo antigo.

33 As fontes antigas relativas a esta questão encontram-se reunidas em MARTINA (1968) 32-50. 
Antes, porém, de avançarmos com a nossa análise, convém dedicar alguma atenção a certos problemas preliminares, cujo entendimento influencia de forma determinante a leitura final da questão. $O$ primeiro consiste em recordar um facto bem conhecido, isto é, que tanto Sólon como Creso constituem duas personalidades reais, de que possuímos dados históricos relativamente precisos. Para o estabelecimento da cronologia relativa entre estas duas figuras, $\mathrm{o}$ aspecto mais importante reside na definição exacta do ano do arcontado de Sólon. ${ }^{34}$ Ora a tradição literária faculta elementos bastante concretos no que se refere a esta questão; entre eles, o passo mais elucidativo é fornecido por Diógenes Laércio (1.62):

[Sólon] floresceu por alturas da quadragésima sexta Olimpiada, no terceiro ano da qual foi arconte em Atenas, tal como afirma Sosicrates; foi então que ele promulgou as leis.

O doxógrafo baseia-se explicitamente em Sosícrates; ${ }^{35}$ de acordo com o seu testemunho, a akme $e^{36}$

${ }^{34}$ Para mais pormenores sobre esta complexa questão, vide LEÂO (2001) 268-75.

35 Sosícrates era uma autoridade reconhecida na discussão da vida e obra dos Sete Sábios, contemporâneo de Apolodoro, e parece ter tido a preocupação de utilizar as melhores fontes ao seu dispor; assim, é provável que o cálculo do mandato de Sólon assente na lista de arcontes epónimos. A conjugação destes factores faz dele uma fonte bastante mais segura do que o próprio Diógenes, o transmissor do seu testemunho. Vide observaçóes de AlEssandrì (1989) 192 e n. 4.

${ }^{36} \mathrm{O}$ 'ponto alto' da vida de uma pessoa, que os antigos situavam por altura dos quarenta anos. 
de Sólon situa-se na 46a Olimpíada (= 596-592), sendo que o arcontado cairia no terceiro ano da mesma Olimpíada, portanto em 594/3. Ainda segundo esta fonte, a nomothesia ou 'actividade legislativa' de Sólon teria ocorrido durante o mesmo período de tempo. Contudo, não é totalmente improvável que, no ano de arcontado, o estadista tenha procedido somente às disposiçóes de emergência (a seisachtheia e a reforma das medidas, pesos e moeda), que complementaria mais tarde (592/1) com o grosso da reforma constitucional. ${ }^{37}$

Relativamente a Creso, a cronologia é menos polémica. Assim, aceita-se, geralmente, que o monarca lídio tenha subido ao trono cerca de 560, governando durante catorze anos seguidos, até que Sardes caiu nas mãos de Ciro, em 547/6. Com estes dados em mente, é chegada a altura de evocar os elementos fornecidos pelo relato de Heródoto (1.29-30.1):

Depois de Creso dominar estes povos e de os anexar à Lidia, passam por Sardes, então no cume da sua riqueza, todos os demais sábios da Hélade que nessa altura viviam, levados cada um por seu motivo. Foi também o caso do ateniense Sólon, que, depois de, a pedido dos Atenienses, ter criado leis, se ausentou da pátria durante dez anos. Embarcou com o pretexto de ir conhecer outras terras, mas, na verdade, fê-lo para não ser constrangido a revogar alguma das leis que estabelecera. É que os Atenienses não

${ }^{37}$ Esta possibilidade tem a vantagem de poder harmonizar o testemunho de Diógenes, em análise, com o de [Aristóteles], Ath. $10.1 ; 14.1$. 
o podiam fazer por si mesmos, pois estavam vinculados por solenes juramentos a respeitar, pelo periodo de dez anos, as leis que Sólon para eles instaurara. E assim por estes motivos e para conhecer outras terras, Sólon abandonou o pais e encontrou-se com Amasis no Egipto e com Creso em Sardes.

Heródoto informa que, logo após a nomothesia, Sólon se ausentou de Atenas durante um período de dez anos, com o pretexto de ir conhecer outras terras, embora o motivo real consistisse na vontade de evitar pressóes para alterar o código de leis que acabara de instaurar. $^{38}$ Vimos, há pouco, que o arcontado do estadista ocorreu em 594/3; ora mesmo admitindo que a reforma legislativa o possa ter ocupado durante mais algum tempo, acontece que o encontro com Creso teria de situar-se durante os dez anos seguintes, portanto até cerca de 580, na melhor das concessóes. Contudo, o monarca lídio atingiu o trono somente em 560, o que inviabiliza a realização histórica do seu encontro com Sólon. De facto, para se manter a hipótese da entrevista, seria necessário alterar vários factores. Antes de mais, o início da viagem decenal teria de ocorrer náo depois do arcontado, mas sim a seguir à primeira tentativa de Pisístrato para instaurar uma tirania em Atenas (561/60). E se isso poderia fornecer um bom motivo para a saída de

${ }^{38}$ Cf. também, a este respeito, os relatos de [Aristóteles] (Ath. 11.1) e de Plutarco (Sol. 25.6). Em todo o caso, não deixa de ser significativo o facto de o autor do tratado aristotélico referir a viagem decenal, mas não mencionar a visita à corte de Creso. 
Sólon, ${ }^{39}$ obrigaria, no entanto, a que se tivesse de baixar consideravelmente a datação do arcontado, além de que levaria a pôr em causa também a provável ocorrência da morte do legislador ateniense em 560/59..$^{40}$ Perante estas múltiplas dificuldades cronológicas, partilhamos a opinião de quantos se pronunciam pela inexistência histórica da entrevista entre Creso e Sólon. ${ }^{41}$ Ainda assim, este episódio faz parte do importante legado cultural grego, pelo que importa reflectir sobre as razóes da sua criação e do interesse que, desde então, atraiu.

A ligação de Creso ao grupo dos Sete Sábios é uma constante na literatura posterior a Heródoto. De resto, Sardes (juntamente com Corinto e Delfos) era frequentemente o local escolhido para situar os encontros das personalidades que integravam aquele

${ }^{39}$ Conforme sustenta Diógenes (1.50), que está empenhado em salientar o desencanto do velho estadista com o rumo político que a sua cidade estava a tomar.

${ }^{40}$ De facto, Heródoto informa que Sardes, na altura em que foi visitada por Sólon, se encontrava no cume do seu poder; seria, portanto, depois da submissão das cidades da Ásia Menor e da aliança com as ilhas gregas, programa que exigiu certamente o decurso de vários anos até ser cumprido, o que equivale a dizer que o encontro com Creso náo poderia dar-se logo no início do reinado.

${ }^{41}$ Que constituem, de resto, a grande maioria. Colocam-se as mesmas dificuldades em relaçáo à passagem pela corte de Âmasis, o último grande faraó da dinastia saíta, pois o seu governo situa-se entre 569 e 525 . Ainda assim, é segura a tradição de que Sólon terá passado pelo Egipto, regiáo que o próprio reformador refere nos seus poemas. Cf. frg. 28 na colectânea de WEST (1992). De resto, Heródoto é a única fonte a referir o nome de Âmasis, cuja ligação a Sólon deve obedecer aos mesmos propósitos éticos que analisaremos em Creso, embora não suscitem o mesmo interesse. 
grupo. ${ }^{42}$ Em todo o caso, na obra de Heródoto o cânone ainda não se encontra estabelecido. Sólon é, portanto, um dos vários sophistai do seu tempo. ${ }^{43}$ Por outro lado, o facto de, na tradiçáo posterior, Delfos ser, conforme vimos, um dos lugares onde os Sete Sábios se reuniam pode constituir um forte indicativo da forma como os nomes de Creso e de Sólon foram associados. Na verdade, o interesse do oráculo pela pessoa do monarca lídio é facilmente compreensível, se aceitarmos a historicidade das magníficas oferendas a Apolo por ele feitas. ${ }^{44}$ Além disso, não é improvável que o próprio Sólon tenha tido um papel de destaque na Primeira Guerra Sacra, conflito que deve ter começado pouco antes do início do arcontado do legislador. De resto, alguns testemunhos chegam mesmo a sustentar que terá cabido a Sólon a proposta de os membros da Anfictionia irem em socorro do oráculo. ${ }^{45}$ Portanto, a propaganda délfica teria todo o interesse em ligar entre si pessoas que haviam desempenhado um papel de relevo na história do oráculo de Apolo. Apesar de verosímil, esta hipótese não é absolutamente necessária, já que bastaria a importância

${ }^{42}$ Vide supra secção 2.

${ }^{43} \mathrm{O}$ termo sophistes é aqui usado com o sentido genérico de 'sábio'; mais adiante (2.49), Heródoto utiliza a mesma palavra para designar o perito em determinada arte, como a dos adivinhos. Somente para finais do séc. V é que o vocábulo se especializa para designar o grupo de figuras (os "sofistas") que cultivavam o enciclopedismo e faziam demonstraçóes públicas de oratória, ministrando um ensino itinerante e remunerado, para grande escândalo dos contemporâneos.

${ }^{44}$ E que o mesmo Heródoto refere (1.50-1). As prodigalidades de Creso encontram confirmação na Ode III de Baquílides.

${ }^{45}$ Cf. Ésquines, 3.108; Plutarco, Sol. 11. 
que rodeava aquelas duas personalidades para justificar que elas fossem, de alguma forma, relacionadas.

Para além destes elementos que poderão ter influenciado as opçóes de Heródoto, interessa agora reflectir, em especial, sobre a maneira como o historiador imaginou a célebre entrevista entre os dois homens. O relato é tão conhecido que dispensaria mais apresentaçôes. Se insistimos em recordá-lo é apenas para tornar mais evidentes certas diferenças de pormenor em relação a outros autores antigos que hão-de basear-se no modelo do historiador.

Ora Creso recebera Sólon no seu palácio e, no terceiro e quarto dias após a chegada, havia instruído os servos no sentido de franquearem ao ilustre hóspede ateniense as riquezas que possuía. Só então, e depois de acentuar a sabedoria do interlocutor, em jeito de captatio beneuolentiae, é que Creso introduz a questão central do diálogo entre os dois homens (1.30.2): «veio-me agora o desejo de te questionar se já viste alguém que fosse o mais feliz (olbiotatos) dos homens». O próprio Heródoto verbaliza aquela que seria a natural expectativa de Creso, fácil de prever depois de o monarca ter feito mostrar os seus tesouros ao visitante. No entanto, o historiador nota que Sólon não se deixou impressionar, facto que, além de salientar o mundo de valores mais elevados em que se move um sábio, faz pensar também que ele irá propor uma redefinição do conceito de olbos, já que em Homero, Hesíodo e poetas da Época Arcaica em geral, o uso dos termos olbos e olbios está ligado sobretudo à 
riqueza material. ${ }^{46}$ Essa conjectura é confirmada logo pela história daquele que ocupa o primeiro lugar na escala da felicidade, Telo de Atenas (1.30.4-5):

Por um lado, este Telo, natural de uma cidade próspera, teve filhos belos e bons e a todos eles viu ter descendência e todos permanecer com saúde; por outro, depois de levar uma boa existência, na medida do possivel, terminou a vida da forma mais brilhante: numa ocasiāo em que os Atenienses entraram em conflito com os seus vizinhos, em Elêusis, ele saiu a terreiro, pôs os inimigos em fuga e pereceu de maneira gloriosa. Os Atenienses sepultaram-no com exéquias públicas, no próprio lugar onde caíra, e prestaram-lhe grandes honras.

É este, portanto, o segredo do 'mais feliz dos homens' (olbiotatos): pertencer a uma cidade digna e próspera; ter filhos que sejam motivo de orgulho e conhecer a descendência deles, livre de perigo; levar uma existência moderada e - aspecto determinante ter um fim de vida glorioso, como representa o facto de se perecer em defesa da pátria.

Era de esperar a surpresa de Creso, perante um quadro táo arredado das expectativas usuais. Mas o monarca insistiu, esperando ocupar ao menos o segundo lugar. Idêntica decepção. Sólon referia agora dois jovens argivos, que possuíam meios de subsistência suficientes, eram dotados de grande força física e haviam sido

${ }^{46}$ É importante salientar, desde já, o facto de a noçâo básica de riqueza que subjaz à pergunta de Creso corresponder ao campo semântico tradicionalmente sustentado pelos aristocratas gregos: a posse de bens materiais. 
mesmo atletas vencedores. Até aqui, estão preenchidos os requisitos relativos à naturalidade, existência moderada, embora ainda curta, e já algumas proezas dignas de nota. ${ }^{47}$ Portanto, a diferença em relação ao caso de Telo deve encontrar-se noutro aspecto. É então que Heródoto narra a história da mãe que tinha de ser transportada num carro ao santuário de Hera; porém, como os bois estavam a ponto de náo chegar a horas, os filhos ocuparam o lugar dos animais e levaram-na ao templo. Até aqui, os dois jovens ainda estão a desempenhar o papel de filhos dedicados e piedosos; a novidade deverá, portanto, buscar-se no desfecho (1.31.3-5):

Depois de assim procederem e perante o olhar da assembleia, chegou-lhes o melhor termo da vida, neles demonstrando a divindade como é melhor para o homem morrer que continuar vivo. [...] A mãe, em júbilo pela empresa e pelo aplauso, de pé frente à estátua, pediu à deusa que concedesse aos seus filhos, Cléobis e Biton, que tamanha honra lhe haviam prestado, a melhor sorte que ao homem pode caber. Depois desta prece, e assim que fizeram o sacrificio e o banquete, os jovens adormeceram no próprio templo e não mais se levantaram; pelo contrário, ai os alcançou o seu fim. Os Argivos ergueram-lhes estátuas e consagraram-nas em Delfos, pois tinham sido homens superiores.

Também no caso de Cléobis e Bíton a hora da morte é determinante, já que os dois irmãos conheceram

${ }^{47}$ Que facilmente nos permitem identificá-los com o nível dos 'filhos belos e bons' do primeiro exemplo. 
o termo da vida num momento de reconhecida glória. O motor involuntário do seu falecimento prematuro foi a própria mãe, ao pedir para os jovens a maior recompensa que ao homem se pode outorgar. E assim, com a sua morte, neles mostrou a divindade que, por vezes, é melhor perecer numa boa altura do que enfrentar um futuro incerto. Ora a razão para se colocar os dois jovens em segundo lugar na escala da felicidade parece caber a esta morte extemporânea, já que, no essencial, a sua história é semelhante à de Telo, na medida em que também perecem num momento de reconhecida glória.

$\mathrm{Na}$ verdade e contrariamente à tendência dominante na Época Arcaica, Sólon sustentava, na sua poesia (e.g. frg. 18 WeST), que a idade avançada também trazia benefícios, em especial no que diz respeito ao progresso intelectual e à ponderaçáo. De resto, um pouco adiante no relato de Heródoto (1.32.2), e embora com a intenção de demonstrar a quantidade de males a que o homem está sujeito durante a existência, o estadista coloca o termo da vida humana aos setenta anos. ${ }^{48}$ Por conseguinte, a concepçáo de felicidade existencial do Sólon histórico aproxima-se mais do exemplo de Telo e daí que este haja sido colocado em primeiro lugar. ${ }^{49}$ WeST).

${ }^{48}$ Ideal expresso também na poesia de Sólon (cf. frg. 27

${ }^{49}$ Telo era originário da mesma cidade que o legislador, pelo que não é improvável que a história possua uma origem ateniense. Quanto ao relato de Cléobis e Bíton, defende-se, com frequência, que tenha raízes argivas e um tratamento e difusão délficos, hipótese reforçada pela descoberta de dois kouroi, por vezes identificados com estes jovens, se bem que haja fortes possibilidades de as 
Perante este segundo exemplo de olbos, Creso já deveria ter compreendido que a essência do conceito não iria incidir sobre a riqueza material, de que ele podia esperar ser um legítimo representante. ${ }^{50}$ Por isso, deseja saber em que posição colocará Sólon a sua eudaimonie ('ventura'), expressão que denota um alargamento de horizontes e, de certa forma, uma concessão, pela parte do rei, para quem a felicidade se concentrava inicialmente apenas no conceito que ele (mas não Sólon) tinha de olbos, enquanto mera abundância de bens materiais. $\mathrm{O}$ legislador esclarece a sua posição na resposta incisiva que dá ao rei, da qual convém recordar os momentos mais significativos para a análise em curso (1.32.1-9):

Ó Creso, tu interrogas-me sobre assuntos humanos e eu sei é que a divindade é toda inveja e perturbação. $\mathrm{Na}$ verdade, com o decorrer do tempo, há que ver muitas coisas sem vontade e outras tantas sofrer. [...] De facto, pareces-me assaz rico e senhor de muitos homens; quanto ao que me perguntavas, não to posso dizer por ora, antes de saber se terminaste bem a vida. Em boa verdade, o dono de grandes fortunas não é mais feliz do que o que possui apenas para o dia-a-dia, se não tiver a sorte de, gozando dessas posses, terminar bem a vida. [...] Antes de atingir o termo, aguarda e não o chames feliz, mas apenas afortunado. [...] De facto, a muitos acenou o deus com a felicidade, para depois os abater pela raiz.

estátuas representarem antes os Dioscuros (Castor e Pólux) e não os dois argivos referidos por Heródoto.

${ }^{50}$ A riqueza dos monarcas lídios era proverbial e, antes de Creso, já em Giges se via o símbolo da opulência oriental. Cf. Arquíloco, frg. 19 WEST. 
A explicação de Sólon vem esclarecer a aparente injustiça da morte prematura de Cléobis e Bíton. O exemplo de Telo mostra nitidamente que o paradigma corresponde a levar uma vida modesta e saudável, conhecer a descendência e, aspecto fundamental, ter uma boa morte, que infunda respeito e admiração nos demais. ${ }^{51}$ Essa ideia está de acordo, como vimos, com a poesia do estadista e é central na resposta agora facultada a Creso. Os dois jovens atletas de Argos ocupam o segundo lugar porque não tiveram uma vida longa e foram, por isso, privados da alegria de ter descendência; mas, atendendo à instabilidade das coisas humanas, por vezes será melhor perecer do que arriscar a perda daquilo que já se julgava seguro, como irá acontecer a Creso. Neste sentido, o rico não se pode dizer mais feliz do que o pobre. ${ }^{52}$

Que na poesia de Sólon encontremos reflexôes frequentes sobre a natureza e papel da riqueza não deve causar-nos surpresa. A sociedade da Época Arcaica, dominada pela aristocracia terratenente, considerava a riqueza um elemento essencial da arete. A novidade encontra-se em o estadista admitir a disjunção destes valores, ao mesmo tempo que afirma a superioridade do segundo. ${ }^{53}$ Naquele que é o seu poema mais extenso, e também o mais complexo (frg. 13 WEST), usualmente

${ }^{51}$ Neste sentido aponta igualmente o frg. 21 WEST de Sólon.

${ }^{52}$ Depois da sua queda às mãos de Ciro e no momento em que se encontrava já na pira, Creso recordará a conversa com Sólon, de que reteve o princípio básico de que, durante a vida, é prematuro considerar alguém feliz (1.86.3).

${ }^{53}$ Frg. 15 WeST. 
conhecido por "Elegia às Musas", Sólon pede às filhas de Zeus e de Mnemósine felicidade da parte dos deuses e a graça de gozar de boa fama junto dos homens, aspecto que já vimos ser importante quer na história de Telo como na dos jovens argivos. $\mathrm{Na}$ mesma elegia, torna claro que, apesar da instabilidade dos bens materiais, ele não deixa de os desejar também para si, mas com uma importante ressalva (vv. 7-13):

Riquezas desejo possuir, mas adquiri-las injustamente não pretendo: sempre, a seguir, vem a justiça. A fortuna que os deuses dão fica ao lado do homem, firme, desde os alicerces à cumeeira.

Porém, a que os homens honram, com insolência, a ordem [devida

não segue, mas, levada por impias acçôes, contrafeita vem atrás e, lesta, se lhe junta a perdiçâo.

A riqueza é legítima quando emana da vontade divina, que lhe garante firmeza e perenidade. Mas aquela que é fruto da insolência (bybris) e da injustiça (adikia) cedo arrasta o homem para as sendas da perdição. Isso acontece porque a demanda desenfreada de riqueza náo respeita a ordem devida e, assim, atrai o golpe da justiça, que, como o poeta diz mais adiante, é desferido por Zeus. ${ }^{54}$

Aplicados ao caso de Creso, estes princípios mantêm-se operantes: o monarca, não contente com o seu poder, deseja expandi-lo para além do

${ }^{54}$ Vv. 17-25. 
razoável. ${ }^{55}$ Por outro lado, a riqueza inicial de Creso, embora herdada, não é totalmente legítima, na medida em que Giges, o primeiro monarca da dinastia dos Mérmnadas, usurpou o trono aos Heraclidas, depois de assassinar Candaules (1.7). Que este factor é importante prova-o o oráculo de Apolo, a quem Creso, depois da queda, foi pedir contas (1.91). A Pítia explicou que Lóxias se tinha esforçado por que o castigo recaísse sobre os filhos de Creso e não sobre o próprio monarca, o que prova o reconhecimento do deus pelas ofertas do rei da Lídia; porém, não conseguiu demover o destino marcado pelas Moiras. Ainda assim, Apolo retardou por três anos a queda de Sardes. Esta informação coloca-nos perante a complexa questão das causas da desgraça de Creso, o que equivale a perguntar se ele expiou uma culpa pessoal se hereditária. A resposta que parece impor-se é a de que o monarca lídio incorreu em ambas. ${ }^{56}$ Ora o Sólon dos poemas também reconhece que a justiça de Zeus pode tardar, mas acaba sempre por chegar. ${ }^{57}$ Portanto, quando Creso paga pela falta do antepassado Giges, é em obediência ao princípio de que a todo o culpado

${ }^{55}$ Como indica, simbolicamente, a travessia da fronteira natural que constitui o rio Hális (1.72).

${ }^{56}$ A análise da história de Creso em termos de enredo trágico encontra bastante eco entre os estudiosos, que têm proposto comparaçóes sobretudo com o princípio esquiliano do pathei mathos ('aprendizagem pelo sofrimento') e com a irónica cegueira do protagonista do Rei Édipo de Sófocles. A título de exemplo, vide Silva (1994), 21-49, esp. 30-1.

${ }^{57}$ Cf. frg. 13.29-32 West: «mas um logo expia a culpa, outro mais tarde; quem a evitar / na sua pessoa, sem que o golpe da moira dos deuses o alcance, / sempre acabará por chegar. Inocentes, as faltas pagarão / os seus filhos ou os filhos destes, mais tarde». 
corresponde uma expiação, ainda que esta possa recair apenas sobre a descendência.

Esta proximidade entre o ideário do Sólon histórico e o da personagem recriada por Heródoto ajuda a entender as razóes que levaram o historiador a optar pela figura do estadista. No entanto, estudiosos há que sustentam que os princípios enunciados exprimem apenas as convicções de Heródoto e não as de Sólon. ${ }^{58}$ Efectivamente, o tema da instabilidade dos assuntos humanos vem introduzido logo nos capítulos em que Heródoto enuncia a intenção de considerar no seu relato quer as cidades grandes como as pequenas (1.5.4) e é retomado, por exemplo, quando ele discute as causas da loucura de Cambises (3.33). A mutabilidade da fortuna leva à suspensão do juízo sobre a felicidade de alguém até que as condiçóes da sua morte iluminem a nobreza da existência que levou. O caso de Prexaspes, nobre persa, ilustra bem o paradigma enunciado. ${ }^{59}$ A contingência de a vida humana estar sujeita às variaçóes da sorte prende-se com o facto de, como Sólon explicava a Creso, «a divindade ser toda inveja e perturbação». O conceito de 'inveja' (phthonos) divina não aparece na poesia de Sólon, enquanto em Heródoto detém uma grande importância. É central na relação entre Âmasis e Polícrates e encontra uma das suas expressóes mais claras nas palavras de Artábano ao sobrinho Xerxes, ao mostrar-lhe como são os animais, as árvores e as casas mais imponentes que atraem o raio divino. A razáo aponta-a logo a seguir

${ }^{58}$ E.g. Shapiro (1996), trabalho que está orientado no sentido de comprovar esse pressuposto.

${ }^{59}$ 3.75.3. Mais exemplos em Shapiro (1996) 358. 
(7.10e): «é que a divindade gosta de abater todo o que se levanta». Portanto, o phthonos dos deuses recai sobre tudo o que ameace ultrapassar o seu natural limite, sejam os animais, as plantas ou as acçóes humanas, pois apenas a si mesma a divindade permite alimentar pensamentos de grandeza. Há, assim, uma relação directa entre hybris e phthonos e a consequência provável será a desgraça do infractor, pois, para Heródoto, os deuses têm a função de manter a ordem e o equilíbrio do mundo. Assim se explica o castigo terrível que tombará sobre Creso em embates sucessivos, até ao dia em que terá de subir à pira preparada pelo vencedor, Ciro. ${ }^{60}$ Portanto, há que reconhecer que, basicamente, as ideias veiculadas pelo Sólon das Histórias também exprimem noções de Heródoto. ${ }^{61}$

Falta, no entanto, analisar uma questão de fundo, muito importante para o entendimento das

${ }^{60}$ Que este tema já tinha uma tradiçáo anterior a Heródoto mostram-no uma ânfora de figuras vermelhas (datada dos inícios do séc. V) e cinco fragmentos de uma hídria de Corinto, também de figuras vermelhas (cerca de 480-450), que parecem representar Creso na pira, e ainda o tratamento que dele faz Baquílides na ode (3.15-62) composta em honra de Hierão de Siracusa, que ganhou a corrida de carros nos Jogos Olímpicos de 468. Na versão de Baquílides, é Creso a decidir sacrificar-se, juntamente com a esposa e as filhas, quando a queda da cidade estava iminente; porém, no derradeiro momento, Zeus extingue as chamas e Apolo leva-os para os Hiperbóreos, graças à piedade do monarca.

${ }^{61}$ Em todo o caso, não deixamos de considerar excessivo o juízo de Plutarco ou Pseudo-Plutarco (Mor. 857f-858a), segundo o qual Heródoto (1.32), ao projectar sobre Sólon as suas concepções religiosas, teria aliado a maldade à blasfémia. Como vimos, à parte a noção de phthonos divino, as ideias expressas nos poemas do legislador concordam, globalmente, com a recriação literária de Heródoto. 
restantes fontes, que consiste em procurar saber se as consideraçôes trocadas entre Sólon e Creso se inserem apenas no quadro da oposição grego/bárbaro ou se visam apontar as limitações de determinado universo axiológico próprio também da sociedade grega. Entre os estudiosos modernos prevalece a primeira interpretação e Heródoto parece sustentar essa hipótese, na forma como introduz o logos do monarca lídio (1.6.2-3):

Foi este Creso, pelo que sabemos, o primeiro entre os bárbaros a submeter ao pagamento de tributo alguns Helenos e a fazer amizade com outros. Submeteu, portanto, os Iónios, os Eólios e os Dórios que moravam na Ásia e fez amizade com os Lacedemónios. Antes do governo de Creso, todos os Helenos eram livres.

Heródoto parece contradizer a afirmação de que teria sido Creso o primeiro a atentar contra a liberdade helénica, ao afirmar que Giges (1.14.4), Árdis (1.15) e Aliates (1.16-22) já tinham, durante o seu reinado, atacado e até mesmo dominado algumas cidades gregas asiáticas (como Mileto, Esmirna, Cólofon, Priene e Clazómenas). Uma forma possível de explicar essa aparente contradição residirá na distinção a estabelecer entre operaçóes de razia (ou incursóes temporárias) e o domínio definitivo. ${ }^{62}$ De momento, porém, este aspecto tem um interesse marginal para os nossos objectivos.

${ }^{62}$ Das campanhas realizadas pelos outros monarcas não tinha resultado uma submissão efectiva e duradoira, como no caso de Creso, de que a obrigação ao pagamento de um tributo, estabelecida por este rei, seria o símbolo visível. 
Digno de maior nota é o facto de Heródoto apresentar Creso na qualidade de um bárbaro, como, de resto, se esperaria, já que, sendo ele rei da Lídia, não poderia integrar o grupo dos Gregos. Contudo, esta informação, que serve ao historiador para preparar o relato das Guerras Medo-Persas, não é explorada no encontro entre Creso e Sólon. O traço do soberano de Sardes que vem repetidamente sublinhado é a sua enorme fortuna, que tanto pode ser positiva (como acontece nas dádivas feitas a Delfos) como negativa, ao despertar sentimentos de hybris. No entanto, já atrás dissemos que esta noção de felicidade assente na posse de bens materiais acaba por ser característica de um ideário partilhado, em termos gerais, pelos aristocratas gregos. ${ }^{63}$ Daí que ganhe pertinência a interpretação que vê nas palavras de Sólon não tanto o espelho da oposição grego/bárbaro, mas antes uma crítica generalizante à concepção mais usual de felicidade, e que encontra apoio, conforme vimos, nos poemas do legislador. ${ }^{64}$ De resto, mais adiante, ao narrar a queda de Sardes às mãos de Ciro, o próprio Heródoto esclarece, pela boca de Creso, o real alcance das palavras de Sólon (1.86.5): «Falava não tanto para si [Creso], mas antes para todo o género humano e, em especial, para aqueles que, no seu íntimo, se julgavam felizes». Portanto, analisar a conversa entre Sólon e Creso à luz

${ }^{63}$ Passos exemplificativos deste universo de valores em De HeER (1969): 12-15 (Homero), 32-38 (Época Arcaica), 67-72 (Época Clássica), só no que diz respeito ao termo olbos.

${ }^{64} \mathrm{Em}$ alguns dos seus versos (em especial no frg. 23 WeST), Sólon também regista algumas notas que se situam na perspectiva tradicional, mas estes parcos exemplos não são característicos do pensamento do estadista expresso na obra poética. 
da relação grego/bárbaro é reduzir o peso ético de um episódio que detém, declaradamente, objectivos muito mais vastos.

Heródoto denuncia as limitaçóes de certa concepção de felicidade, que não é exclusiva de um bárbaro, mas pode estender-se à própria aristocracia grega e ao género humano em geral. Serve-se, para isso, de duas figuras históricas que recria no sentido de acentuar os dois aspectos em debate: por um lado, a enorme riqueza de um monarca, que pode levar à cegueira arrogante; por outro, a ponderada visão de um estadista e pensador que teve a preocupação de evitar os caminhos do excesso - e da perdição que geralmente the anda associada. Creso e Sólon acabam, assim, por ultrapassar as fronteiras da sua existência histórica para atingirem o estatuto de paradigma. ${ }^{65}$

Depois de analisarmos o relato que servirá de modelo às abordagens subsequentes, interessa agora reflectir sobrealguns dos testemunhos mais dignos de nota e ponderar as semelhanças e diferenças relativamente a Heródoto. A próxima fonte que relaciona expressamente as duas personalidades em análise é da responsabilidade de Platão, numa altura em que fala da tendência natural que a sabedoria (phronesis) e o poder (dynamis) têm para se associarem. No seguimento, o autor ilustra o que acabara de afirmar com vários exemplos, que iremos em parte recordar (Ep. 2.311a):

${ }^{65} \mathrm{Na}$ parte final da interpretação do relato de Heródoto, aceitamos o essencial do interessante estudo de Duplouy (1999), esp. 1-9 e 21-2. 
Assim, também quando as pessoas falam de Hierão e do lacedemónio Pausânias, fazem questão de referir a sua ligação a Simónides, bem como o que este fez e disse a respeito deles. Costumam, ainda, fazer o elogio conjunto de Periandro de Corinto e de Tales de Mileto, de Péricles e Anaxágoras, de Creso e Sólon, na qualidade de sábios, e de Ciro, na de soberano.

De momento, deixamos para segundo plano os restantes pares de exemplos para nos centrarmos em Creso e Sólon. Seria possível evocá-los a ambos como símbolo de poder ou entáo referir o primeiro enquanto homem de Estado e o segundo no papel de sábio, como acontece no relato de Heródoto. No entanto, Platão prefere atribuir aos dois o papel de sapientes; ${ }^{66}$ assim, cabe ao persa Ciro a representação do poder. Este pormenor vem acentuar a ideia de que o rei da Lídia náo era visto pelos Gregos como um simples bárbaro. De resto, com o historiador de Halicarnasso, Creso assumira também, por várias vezes, o papel de conselheiro. ${ }^{67}$

Ora quando Diodoro aborda este mesmo episódio, havia muito tempo já que os elementos fundamentais da tradição relativa aos Sete Sábios se encontravam fixados. Aliás, o autor atribui muita importância à vertente sapiencial da existência de Sólon, quer ao falar da formação do estadista quer ao referir os aspectos mais

${ }^{66}$ Daí que não haja motivo para Platão referir os pormenores da conversa entre Creso e Sólon.

${ }^{67}$ Precisamente junto de Ciro (e.g. 1.155-6; 207-8). 
importantes da sua actividade. Diodoro menciona a relação entre o legislador ateniense e Creso por três vezes, com algumas variantes dignas de nota. Na primeira delas (9.2.1-4), Sólon aparece como o único interlocutor do monarca lídio cuja resposta é reproduzida. E com efeito, a forma como ambos os homens aí são apresentados merece ser recordada, ao menos em parte (9.2.1-2):

Ora Creso, rei dos Lidios, que era possuidor de grandes recursos e havia acumulado, de forma deliberada, muita prata e ouro, costumava convocar os mais sábios de entre os Helenos e, depois de com eles conviver, despedia-os com muitos presentes e ele próprio lhes ficava a dever muito na busca da virtude. Em certa altura, mandou chamálo [a Sólon] e, depois de the ter mostrado os seus recursos e riqueza, perguntou-lhe se the parecia que existia alguém que fosse mais feliz do que ele próprio. [...] Ele respondeu-lhe que, na verdade, era necessário ver o fim da vida, e somente a pessoa que, até então, continuasse a ser afortunada é que poderia, com propriedade, dizer-se feliz.

Diodoro começa por acentuar a enorme dimensão do poder e riqueza de Creso, cuja acumulação obedecera a um projecto consciente que, sem ser claramente identificado, deve corresponder à vontade de impressionar as pessoas que o rei convocava para a sua corte. $O$ facto de esses ilustres visitantes serem os mais sábios de entre os Helenos vem acentuar a pertinência da interpretaçáo da troca de impressóes com Sólon à luz da oposição grego/bárbaro. Contudo, 
esta leitura, que tenderia a ser desfavorável ao monarca lídio, encontra-se mitigada por vários elementos. Antes de mais, pelo pormenor significativo de, no convívio com os 'mais sábios', Creso não buscar propriamente a adulação, mas antes a possibilidade de aperfeiçoar o conhecimento da virtude. ${ }^{68}$ Esta preocupação louvável do monarca é reforçada pelo contexto que antecede o passo transcrito, onde se descreve a forma como Sólon terá procurado disciplinar o espírito indolente dos seus concidadáos (9.1.4). Quanto à pergunta de Creso e à resposta que lhe é facultada pelo legislador ateniense, nela se reconhecem claramente as linhas essenciais do relato de Heródoto: a concepção diferente de riqueza/felicidade que assiste aos dois homens e a necessidade de esperar pelo fim da vida até se fazer um diagnóstico seguro da existência. Contudo, Diodoro não regista os exempla fornecidos por Sólon (relativos a Telo, Cléobis e Bíton), omissão que se verifica, de resto, em todos os passos onde o autor evoca este episódio. ${ }^{69}$ Diodoro encerra (9.2.3-4) com a descrição sumária da sorte de Creso às mãos de Ciro, segundo os parâmetros usuais, se bem que registe uma oscilaçáo que derivará, provavelmente, de um desdobramento da mesma tradição. Segundo Heródoto (1.86.5-87.2), Ciro terá ordenado que fossem apagadas as chamas da pira; perante a impossibilidade de controlo

${ }^{68} \mathrm{O}$ que ajuda a compreender que Diodoro não registe, neste passo, qualquer reacção negativa do tirano perante a resposta de Sólon.

${ }^{69}$ Facto que talvez se justifique por esses elementos serem já muito conhecidos, como afirma Diógenes Laércio, em passo que adiante retomaremos (1.50). 
do fogo, seguiu-se a invocação de Creso e a tempestade salvadora enviada por Apolo. Diodoro começa por afirmar somente que as chamas foram extintas por ordem de Ciro (9.2.4); mais adiante (9.34), porém, refere apenas a tempestade, onde vê a marca da piedade de Creso, facto que leva Ciro a fazer dele seu conselheiro e a contá-lo entre os sábios. ${ }^{70}$

À parte o interesse destes pormenores, acabam por ser mais significativas as diferenças registadas no passo mais extenso que o mesmo Diodoro dedica ao célebre episódio. Destaca-se, desde logo, a forma contrastante como é feita a apresentação do monarca e dos seus propósitos (9.26.1):

Ora Creso costumava convocar da Hélade as pessoas que mais se distinguiam pela sabedoria e, ao exibir-lhes a magnitude da sua felicidade, honrava, com esplêndidas dádivas, quem celebrasse a sua boa fortuna. Mandou, então, chamar Sólon, bem como os outros que gozavam de maior fama na dedicação à sabedoria, na expectativa de, com o testemunho destes homens, ver aplicado o selo do reconhecimento sobre a sua própria felicidade.

No primeiro passo que comentámos, Diodoro acenava à vaidade de Creso com uma nota breve e discreta; agora, porém, este elemento torna-se central na caracterizaçấo do monarca. Na verdade, Diodoro dissera antes que o rei da Lídia recompensava os ilustres visitantes que convocava, mas fazia-o em troca da oportunidade

${ }^{70}$ Elemento que, conforme vimos, também já se encontra presente em Heródoto. 
para aprofundar o conhecimento da virtude. Contudo, no texto em análise, os presentes de hospitalidade, embora igualmente magníficos, destinam-se a premiar somente quem adular a riqueza que o tirano possui. O Creso agora apresentado não deseja aprender nada; pretende somente 'comprar' a opiniáo de mensageiros afamados que confirmem, no exterior, a grandeza do seu poder. $\mathrm{O}$ monarca assume, desta forma, os traços do bárbaro arrogante que espera deslumbrar, com a exibição do seu poder, os representantes do ponderado civismo helénico. Por tal motivo, não surpreende agora que Creso interrogue, sucessivamente, vários dos Sábios, na expectativa de obter uma resposta lisonjeira. Sofre, no entanto, idêntica decepção com Anacársis, Sólon, Bias e Pítaco. As palavras de Sólon correspondem, no essencial, às linhas básicas analisadas já em Heródoto: porque a fortuna é mutável, há que esperar pelo fim da vida para avaliar correctamente a existência de alguém. Ainda assim, Diodoro não refere, uma vez mais, o caso probatório de Telo e dos dois jovens argivos. Regista (9.27.1-2), no entanto, uma significativa inversão do caminho descrito pelo Creso de Heródoto. Quando, no relato do historiador, ele questionava Sólon sobre a felicidade, começou por acentuar a noção de riqueza material (olbiotatos), para dar lugar a um alargamento de horizontes (eudaimonie), que anunciava, de alguma forma, a futura evolução do pensamento do monarca. Em Diodoro, porém, ocorre o processo contrário, facto que mais acentua a mesquinhez de entendimento do monarca lídio: começa por valorizar a noção de felicidade 
(eudaimonestatos), mas acaba por confiná-la à abundância dos bens materiais (plousiotatos). ${ }^{71} \mathrm{~A}$ oposição grego/ bárbaro é acentuada, também, quando Creso interroga Pítaco sobre qual será a melhor forma de governo, ao que o sábio responde (9.27.4): “A da madeira pintada” — referindo-se às leis». Como facilmente se depreende, na base desta resposta encontra-se a ideia de que Creso, sendo um tirano, se julgaria acima da lei, ao contrário de um cidadão grego, para quem as normas da pólis eram o verdadeiro governante.

Por conseguinte, do testemunho de Diodoro pudemos constatar, no primeiro passo comentado, que ainda nos é apresentada uma imagem de Creso permeada de conotaçóes positivas, onde facilmente se adivinha o papel de conselheiro. Contudo, o extracto mais extenso deste autor mostra como, a par da fixação dos elementos relativos à tradição dos Sete Sábios, se acentuava também a tendência para tipificar os dados relativos à entrevista entre Sólon e Creso, bem como a sua leitura dentro da lógica de oposição grego/bárbaro. ${ }^{72}$

${ }^{71}$ Contrariamente ainda ao Sólon de Heródoto, a personagem de Diodoro tende a rejeitar toda a riqueza material, por considerá-la imoral. Conforme vimos, o Sólon histórico náo sustentava esta perspectiva. Não é improvável que a versão de Diodoro acuse a influência recente da filosofia cínica, conforme sustenta SANTONI (1983) 136-138. Ainda segundo esta estudiosa, a dupla forma como Creso interroga Sólon ajuda a acentuar a total separação entre bens espirituais (a verdadeira felicidade interior) e posses materiais.

72 À presença destas duas vertentes no testemunho de Diodoro talvez não seja alheio, também, o uso de fontes distintas relativamente ao tema dos Sete Sábios. SANTONi (I983), 134 n. 159, encontra-se entre os estudiosos que aventam a dupla influência de Éforo e de Hermipo. 
De acordo com o estado actual das fontes, cabe a Plutarco não só o maior número de referências ao episódio que nos tem ocupado, como ainda a sua abordagem mais elaborada e completa a seguir a Heródoto. Algumas das referências ocorrem de forma dispersa nos Moralia. ${ }^{73}$ Detêm, no entanto, um carácter generalizante e, por esse motivo, não justificam uma atenção demorada, sobretudo quando comparadas com o espaço que, na Vida de Sólon, o polígrafo de Queroneia dedica à celebrada conversa entre Sólon e Creso. O relato ocupa dois longos capítulos, que representam um dos momentos em que Plutarco trabalhou com mais cuidado a forma de expressão, claro indício do interesse que o episódio nele havia despertado. Em termos latos, pode dizer-se que a exposição segue as linhas essenciais presentes na versão de Heródoto, com a amplificação de alguns elementos e resumo de outros, como é prática corrente em autores que tratam um tema comum. No entanto, o aspecto mais digno de nota reside nas profundas diferenças que ocorrem na apresentação da figura do monarca lídio. Efectivamente, depois de acentuar a simplicidade de gostos de Sólon perante o fausto da corte lídia, Plutarco introduz a figura do rei nestes termos (Sol. 27.3-4):

[Creso apresentou-se] coberto de pedrarias, de vestes coloridas, de artísticos ornamentos de ouro, de todo o atavio que possuia e considerava distinto, magnifico e invejável,

73 58e; 69e; 155b; 857f-858a; já nos referimos ao último passo, ao discutirmos a proximidade entre o Sólon histórico e a personalidade recriada por Heródoto. 
de forma a que a sua contemplação fosse o espectáculo mais venerável e variegado de todos. Sólon, porém, depois de estacar diante dele, não sentiu nem exclamou, perante tal visão, nada do que Creso esperava. Pelo contrário, era notório, a quem tivesse bom entendimento, que ele desprezava esta falta de gosto e mesquinhez.

É curioso notar que Plutarco, ao contrário de Heródoto, faz com que a própria aparição de Creso seja deliberadamente retardada, acentuando a vaidade do monarca com a acumulação de pormenores ligados à descrição do seu rico vestuário, antes mesmo de franquear os tesouros ao hóspede ateniense. O objectivo do rei é fazer de si mesmo o mais deslumbrante dos espectáculos. Esta intenção é confirmada pelo próprio Creso, mais tarde, ao esclarecer perante Ciro o sentido da evocaçáo do nome de Sólon. Quando, no passado, o convidara a estanciar junto de si, não o fizera com o intuito de aprender, mas antes com propósitos bem menos elevados: "para ser espectador da minha pessoa e, ao partir, testemunha daquela felicidade, cuja perda é mais dolorosa do que o gosto de a possuir». ${ }^{74}$ Ora ainda antes de Plutarco colocar na boca de Creso a famosa pergunta, já a atitude de Sólon visualizava o fosso de percepção que existia entre si e o tirano. A exuberância do monarca oriental mais não era, para quem tivesse

74 Sol. 28.4. Esta ideia encontra-se igualmente expressa nos Moralia (155b). Já encontrámos idêntica perspectiva em Diodoro (9.26.1), se bem que, conforme vimos, neste autor ela coexista ainda com a noçáo de que Creso, ao conviver com os sábios da Hélade, também procurava aperfeiçoar-se no caminho da virtude (9.2.1). 
espírito avisado, do que a expressão visível da limitação do seu entendimento interior. A narrativa sugeria assim, com intensidade crescente, o que o legislador ateniense acabará por explicar, de forma clara, a um soberano já visivelmente contrariado (Sol. 27.8-9):

Sólon, que o não queria adular nem aumentar-lhe a irritação, retorquiu: "Aos Helenos, rei dos Lídios, concedeu o deus em tudo observar a justa medida e a esta moderação devemos uma sabedoria prudente como convém ó e plebeia, não real ou resplandecente. Eà vista das vicissitudes de todo o género a que sempre anda sujeita a vida, não permite ter em grande conta os bens presentes nem admirar a fortuna de um homem quando ela ainda está a tempo de se alterar. Em boa verdade, a cada um reserva o futuro sorte vária e desconhecida. Aquele a quem até ao fim a divindade concedeu o sucesso, a esse consideramos feliz.»

A noção de mutabilidade da fortuna e a necessidade de suspensão do juízo sobre a felicidade de alguém até se conhecer o final da sua existência estão, efectivamente, no relato de Heródoto, mas o objectivo das palavras de Sólon é bastante diferente. Para Plutarco, não se trata apenas de enunciar um princípio aplicável a todo o género humano. $\mathrm{O}$ biógrafo pretende salientar também a diferente capacidade de percepção que existe entre um cidadáo grego e um bárbaro. Faz, assim, o elogio da sábia consciência da justa medida — própria do cidadão de uma pólis — perante a cega exuberância de um monarca oriental. Nenhum dos testemunhos até 
agora analisados havia chegado a este ponto. De facto, é neste passo de Plutarco que encontramos a expressão mais clara e inequívoca da oposição grego/bárbaro no contexto da célebre entrevista que tem motivado as nossas indagaçóes.

Comentaremos apenas mais um autor, Diógenes Laércio, não só por constituir uma das fontes mais extensas sobre Sólon, como ainda por representar, conforme vimos (supra secção 2), um estádio da tradição onde os elementos relativos ao legislador ateniense e ao monarca lídio já se encontravam bem cristalizados. Esta realidade detém, por si só, algum interesse, mas o aspecto mais revelador reside, novamente, no significado a atribuir às diferenças de pormenor presentes na abordagem de Diógenes. O primeiro aspecto a merecer reflexão prende-se com o facto de o doxógrafo colocar a viagem de Sólon no período imediatamente a seguir à primeira tentativa de instauração da tirania de Pisístrato, portanto cerca de 561/60. Já atrás nos pronunciámos pela improbabilidade desta leitura que viria somente acrescentar ainda mais problemas à tabela cronológica de Heródoto, que suscitava, por si só, fundamentadas reservas. É, no entanto, reveladora das intençôes de Diógenes (e, certamente, de algumas das suas fontes), uma vez que esta datação permitiria enquadrar o exílio voluntário do velho legislador (e primeiro 'democrata') dentro da oposição ao regime tirânico de Pisístrato. ${ }^{75}$

${ }^{75}$ Para mais pormenores sobre esta vertente da tradição, vide LEÃo (2008b). 
No mesmo passo onde sustenta esta perspectiva (1.50), Diógenes menciona a deslocação ao Egipto, a Chipre e, finalmente, a Sardes. A conversa com Creso vem então referida de forma sintética e nela não figura, sequer, um traço comoa riqueza do monarca oriental-determinante na evolução do relato. À esperada indagação sobre a felicidade, Sólon responde apenas com a referência aos nomes de Telo, Cléobis e Bíton. Os outros pormenores são resumidos com uma expressão vaga («e o resto, que toda a gente conhece»), claro indício de que faziam parte de um património cultural bem familiar. Em vez desses elementos tradicionais, Diógenes opta por facultar outros dados pitorescos que foram transformando o modelo fornecido por Heródoto, conforme acontece usualmente no processo de amplificação lendária. Entre eles, encontra-se a correspondência que Sólon teria trocado com personalidades como Periandro (1.64), Epiménides (1.64-6) e Pisístrato (1.66-7). Estas cartas constituem, seguramente, documentos forjados, que devem ser lidos à luz da tradição dos Sete Sábios e das discussóes sobre a melhor forma de governo. ${ }^{76}$ Pode, por conseguinte, adiantar-se a mesma explicação para a missiva destinada a Creso; ainda assim, valerá a pena recordá-la, por nela se detectarem as marcas do problema que temos procurado analisar (1.67):

Sólon a Creso

Admiro-te pela bondade demonstrada em relação à

${ }^{76}$ Cf. supra secção 2. 
minha pessoa e, por Atena, náo colocasse eu acima de tudo o desejo de viver em democracia, e mostraria como é preferivel fixar residência no teu palácio a fazê-lo em Atenas, onde Pisistrato procura exercer pela força o poder absoluto. É-me, porém, mais agradável a vida onde todos partilham a justiça e a igualdade. Ainda assim, conto visitar-te, pois desejo profundamente tornar-me teu hóspede.

Neste bilhete, não encontramos sinais que sugiram, de forma clara, uma caracterização negativa de Creso. Pelo contrário, Sólon confessa-se honrado pela atenção que despertara em Creso e até mostra sentir-se atraído pela ideia de viver em Sardes. ${ }^{1} \mathrm{O}$ motivo reside no facto de Atenas estar a ponto de ser dominada por um governo tirânico. ${ }^{2}$ Ora é somente esta sugestão que permite enquadrar as palavras de Sólon dentro do espírito da oposição grego/bárbaro. Não fosse a preferência pelo regime democrático, onde todos partilham a mesma noção de justiça e de igualdade, e Sólon teria preferido a corte do rei. $\mathrm{Na}$ base da argumentação, identifica-se com facilidade a noção da supremacia de certas conquistas civilizacionais gregas (como a soberania da lei) sobre o regime autocrático

${ }^{1}$ Teoricamente, a carta em análise havia sido escrita antes da visita à corte de Creso, pelo que, depois de conhecer pessoalmente o monarca, Sólon poderia ter mudado de opiniáo. Contudo, há que reconhecer que esta hipótese é um simples exercício de especulação, que não encontra apoio no texto de Diógenes.

2 Apesar de a missiva destinada a Creso ser a última que Diógenes transcreve, esta carta deveria figurar em primeiro lugar, pois Sólon encontra-se em Atenas e a tirania de Pisístrato ainda não era um facto consumado. 
aceite pelos bárbaros. No entanto, esta ideia é remetida para segundo plano e desautorizada, em grande parte, pelo facto de Atenas estar também às portas da tirania. ${ }^{3}$ Por conseguinte, a caracterização de Creso acaba por ser maioritariamente favorável ao rei da Lídia.

A análise diacrónica dos principais testemunhos relativos à entrevista entre Sólon e Creso mostra que este relato foi aproveitado de maneira diferente ao longo dos tempos. Se, em Heródoto, o episódio se destina sobretudo a definir uma ética de aplicação universal, já em Plutarco encontramos a expressão mais enérgica da oposição grego/bárbaro, ainda que dela resultem, igualmente, significativas implicaçóes morais. As restantes fontes movimentam-se entre estas duas perspectivas, que privilegiam de forma variável. $\mathrm{Na}$ verdade, a correcta interpretação daquele encontro já dividia os antigos, como nos mostra o elucidativo testemunho de Plutarco, que nos parece vantajoso recordar no encerramento deste estudo (Sol. 27.1):

Quanto ao seu encontro com Creso, alguns são de opinião que não passa de uma invenção, argumentando com a cronologia. Pela minha parte, contudo, um relato assim

${ }^{3}$ Ainda assim, Diógenes não acentua muito o carácter negativo do governo de Pisístrato, talvez por este último ocupar também, por vezes, o posto de sábio, conforme regista o mesmo Diógenes (1.122). Aliás, esta noção concorda, em termos gerais, com o retrato da tirania de Pisístrato, facultado, a título de exemplo, por [Aristóteles] (Ath. 16), que compara esse período a uma nova idade de Cronos. 
famoso, atestado por tantos testemunhos e, o que é mais importante, conforme ao carácter de Sólon e digno da sua magnanimidade e sabedoria, não me parece que seja de o pôr de lado à conta de uns quadros cronológicos, que tantos estudiosos procuraram, até hoje, corrigir, sem que tenham conseguido reduzir as contradiçóes a algum resultado que eles próprios aceitem.

Quando refere a polémica que envolvia a célebre conversa entre Sólon e Creso, o biógrafo de Queroneia acaba por dar, igualmente, a justificação para o seu estudo, ao mencionar o elevado interesse moral do episódio. De resto, terá sido esse motivo que o levou a alongar-se na descrição da lendária visita à corte de Creso. Ora é o reconhecimento dessa elevada mensagem ética que nos deve impelir, também hoje, a seguir a argumentação do legislador ateniense e a surpresa crescente do monarca lídio, pois nelas encontramos uma das mais felizes expressôes do valor paradigmático da cultura clássica. Foi este, igualmente, o objectivo pretendido pelas diferentes abordagens que, ao longo dos tempos, enriqueceram a tradição dos Sete Sábios: recuperar e reescrever todo um legado civilizacional, de forma a colocá-lo ao serviço dos interesses formativos de cada época, enquanto veículo privilegiado de paideia. 


\section{Bibliografia}

Aalders, G. J. D.: "Political thought in Plutarch's Convivium Septem Sapientium", Mnemosyne 30 (I977) 28-39.

Alessandrì, Salvatore: "I viaggi di Solone", CCC 10 (1989) 191-224.

Busine, Aude: Les Sept Sages de la Grèce antique. Transmission et utilisation d'un patrimoine légendaire, d'Hérodote à Plutarque (Paris, 2002).

Defradas, Jean, Hani, Jean \& KLaerr, Robert: Plutarque. Oeuvres Morales. Tome II (Paris, 1985).

VAN Dijk, Gert-Jan: "Esopo, Plutarco, Platón y Aristóteles. La función de la fábula y el arte de la alusión”, in A. Pérez Jiménez, J. García López \& Rosa M. Aguilar (eds.), Plutarco, Platón y Aristóteles (Madrid, 1999), 141-156.

Duplouy, Alain: "Lutilisation de la figure de Crésus dans l'idéologie aristocratique athénienne. Solon, Alcméon, Miltiade et le dernier roi de Lydie", AC 68 (1999) 1-22.

FeHLING, Detlev: Die Sieben Weisen und die frühgriechische Chronologie. Eine traditionsgeschichtliche Studie (Bern, 1985). 
García Gual, Carlos: "Esopo en Plutarco", in M. García Valdés (ed.), Estudios sobre Plutarco: ideas religiosas (Madrid, 1994), 605-614.

Gigante, Marcello: "Biografia e dossografia in Diogene Laerzio", Elenchos 7 (1 986) 7-102.

DE HeEr, C.: Makar-eudaimon - olbios - eutyches. A study of the semantic field denoting happiness in ancient Greek to the end of the 5th century B.C. (Amsterdam, 1969).

Kindstrand, Jan Fredrik: "Diogenes Laertius and the Chreia tradition”, Elenchos 7 (I 986) 217-243.

LatTImore, Richmond: "The wise adviser in Herodotus", CPh 34 (1939) 24-35.

LEÂO, Delfim Ferreira: "Sólon e Creso: fases da evolução de um paradigma”, Humanitas 52 (2000) 27-52. Sólon. Ética e Política (Lisboa, 2001).

“ “Os Sete Sábios como agentes de formação”, Biblos. Culturas em diálogo n.s. 1 (2003) 23-41.

"Matéria religiosa: processos de impiedade (asebeia)", in D. F. Leão, L. Rossetti e M. do Céu Fialho (eds.), Nomos. Direito e sociedade na Antiguidade Clássica I Derecho y sociedad en la Antigüedad Clásica (Coimbra e Madrid, 2004), 201-226.

- Plutarco. Obras Morais - O banquete dos Sete Sábios. Tradução do grego, introdução e notas (Coimbra, 2008a). 
"A sophos in arms: Plutarch and the tradition of Solon's opposition to the tyranny of Pisistratus", in J. R. Ferreira, L. Van der Stockt \& M. do Céu Fialho (Eds.), Philosophy in society. Virtues and values in Plutarch (Leuven and Coimbra, 2008b), 129-138.

"The tyrannos as a sophos in the Septem Sapientium Convivium", in J. R. Ferreira, D. Leão, M. Tröster \& P. B. Dias, Symposion and Philanthropia in Plutarch (Coimbra, 2009), 511-521.

Martina, Antonio: Solon. Testimonia veterum (Roma, 1968).

Mossman, Judith: "Plutarch's Dinner of the Seven Wise Men and its place in symposion literature", in J. Mossman (ed.), Plutarch and his intellectual world (London, I997), 119-140.

Murray, Oswyn: "Sympotic history", in O. Murray (ed.), Sympotika. A symposium on the Symposion, (Oxford, 1994), 3-13.

Pordomingo Pardo, Francisca: "El banquete de Plutarco: ¿ficción literaria o realidad histórica?”, in J. G. Montes Cala, M. Sánchez Ortiz de Landaluce \& R. J. Gallé Cejudo (eds.), Plutarco, Dioniso y el Vino (Madrid, 1999), 379-392.

Rodríguez Adrados, Francisco: "Géneros helenísticos en el Banquete de los Siete Sabios de Plutarco", in J. A. Fernández Delgado \& F. Pordomingo Pardo 
(eds.), Estudios sobre Plutarco: aspectos formales (Salamanca, 1996), 125-142.

Santoni, Anna: "Temi e motivi di interesse socio -economico nella leggenda dei 'Sette Sapienti'", ASNP 13 (1983) 91-160.

Shapiro, Susan O.: "Herodotus and Solon", ClAnt 15 (1996) 348-364.

Schmidt, Thomas S.: Plutarque et les Barbares. La rhétorique d'une image (Louvain, 1999).

Silva, Maria de Fátima: "Creso e Ciro. A figura do rei no Livro I de Heródoto", in Heródoto. Histórias - Livro $1^{\circ}$ (Lisboa, 1994), 21-49.

Snell, Bruno: Leben und Meinungen der Sieben Weisen (München, 1952).

Stadter, Philip A.: "Drinking, Table Talk, and Plutarch's contemporaries”, in J. G. Montes Cala, M. Sánchez Ortiz de Landaluce \& R. J. Gallé Cejudo (eds.), Plutarco, Dioniso y el Vino (Madrid, 1999), 481-490.

Wehrli, Fritz: "Gnome, Anekdote und Biographie", MH 30 (I973) 193-208.

West, M.L.: The east face of Helicon. West Asiatic elements in Greek poetry and myth (Oxford, 1997). 